\title{
DEL 101963 \\ Water-Supply Characteristics of Streams in the Delaware River Basin and in Southern New Jersey
}

GEOLOGICAL SURVEY WATER-SUPPLY PAPER 1669-N

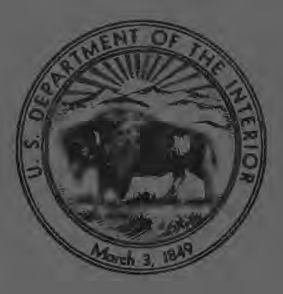




\section{Water-Supply Characteristics}

\section{of Streams in the Delaware}

River Basin and in Southern

New Jersey

By C. H. HARDISON and R. O. R. MARTIN

CONTRIBUTIONS TO THE HYDROLOGY OF THE UNITED STATES

GEOLOGICAL SURVEY WATER-SUPPLY PAPER 1669-N

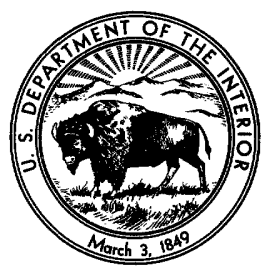




\section{UNITED STATES DEPARTMENT OF THE INTERIOR}

STEWART L. UDALL, Secretary

\section{GEOLOGIGAL SURVEY}

Thomas B. Nolan, Director 


\section{CONTENTS}

\begin{tabular}{|c|c|}
\hline & Page \\
\hline Abstract_- & N1 \\
\hline Introduction & 1 \\
\hline Basic data for the analyses & 2 \\
\hline Flow-duration curves _...... & 8 \\
\hline Low-flow frequency curves & 9 \\
\hline Storage-required frequency curves & 17 \\
\hline Areal draft-storage relationships. & 26 \\
\hline Referencess & 27 \\
\hline
\end{tabular}

\section{ILLUSTRATIONS}

Plate 1. Relation of arrayed annual minimum discharge to minimum 7-day discharge for concurrent years at a pivot station and at an index station in Delaware River basin, Pa., 1936-52 . . . . . . .

Figure 1. Map of Delaware River basin showing location of streamgaging stations and basin outlines......................

2, 3. Flow-duration curves for-

2. Nine stream-gaging stations in the upper part of Dela-

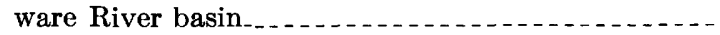

3. Eight stream-gaging stations in the lower part of Delaware River basin

4. Flow-duration tables for six stream-gaging stations affected by regulation and diversion in Delaware River basin ....

5. Effect of regulation and diversion on flow-duration curves for Delaware River at Port Jervis, N.Y., and Wallen-

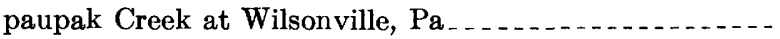

6. Relation of arrayed annual minimum discharge at two pivot stations in Delaware River basin, 1913-52...........

7. Low-flow frequency curves for Brandywine Creek at Chadds Ford, Pa., 1913-52 . . . . .

8. Draft-storage curves for a 10-year recurrence interval at 11 stream-gaging stations in upper part of Delaware River basin

9. Draft-storage curves for a 10-year recurrence interval at eight stream-gaging stations in lower part of Delaware River basin.

10. Frequency-mass curve and draft-storage lines for a 10year recurrence interval, Beaver Kill at Cooks Falls, N.Y 
Figure 11. Storage-required frequency curves for four stream-gaging stations in Delaware River basin . . . . . . . . . . .

12. Areal draft-storage relationships as a function of median annual low flow, Delaware River basin ............

13. Map of median annual low flow for Delaware River basin showing minimum 7-day discharge at the 2-year recurrence interval for unregulated stream gaging stations...-

\section{TABLES}

TABLE 1. Annual low-flow data for Brandywine Creek at Chadds Ford, $\mathrm{Pa}$

2. Annual duration-table data for Brandywine Creek at Chadds Ford, Pa

Page

N4

6

3. Duration of daily flow per square mile at stream-gaging stations in Delaware River basin ..................

4. Duration of daily flow at stream-gaging stations in Delaware River basin

5. Magnitude and frequency of annual low flow at streamgaging stations in Delaware River basin............

6. Indices of low flow at stream-gaging stations in Delaware

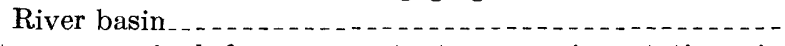

7. Storage-required frequency at stream-gaging stations in Delaware River basin as computed from low-flow frequency data 


\title{
CONTRIBUTIONS TO THE HYDROLOGY OF THE UNITED STATES
}

\section{WATER-SUPPLY GHARAGTERISTIGS OF STREAMS IN THE DELAWARE RIVER BASIN AND IN SOUTHERN NEW JERSEY}

\author{
By C. H. Hardison and R. O. R. Martin
}

\begin{abstract}
The annual low flows at short-term stream-gaging stations in the Delaware River basin are compared with the annual low flows at long-term stations to determine the magnitude and frequency of annual low flows at 95 stream-gaging stations for the period 1913-53. Flow-duration curves for essentially the same period of years are shown for 23 of the stations. For 19 of the stations the low-flow frequency curves are used to estimate the magnitude and frequency of storage required to maintain selected draft rates.

Median values of annual low flow at the 95 stations range from 0.02 million gallons per day per square mile to $\mathbf{0 . 6 5}$ million gallons per day per square mile and vary widely even between stations on adjacent streams. The annual 7-day low flow for the 20-year recurrence interval averages about half that for the 2-year recurrence interval (median annual 7-day flow) and ranges from 25 to 79 percent.

The median annual 7-day low flow, when expressed as flow per square mile, is a good index of the allowable draft for selected amounts of storage required at selected recurrence intervals. For a storage of 20 million gallons per square mile at a 10-year recurrence interval, the allowable draft for all but 2 of the 19 stations analyzed plots within 10 percent of the average relation based on data for the 19 stations.
\end{abstract}

\section{INTRODUCTION}

The usefulness of the streams in the Delaware River basin depends largely on the amount of flow during low-flow periods. Because the amount of low flow varies from year to year as well as from stream to stream, wise development requires knowledge of both the frequency distribution of annual low flows and the effect of physical differences between streams. In the analyses in this report, seven long-term records are used to evaluate the year to year variation in low flow and many short-term records are used to determine the variation between streams, so that the low-flow characteristics can be estimated for the sites of most gaging stations. This report includes a summary of these estimates and a description of the methods used in making 
them. The analyses were made as part of a Geological Survey project to supplement material on general geology and ground water that was being prepared for a report on the Delaware River basin (U.S. Army Corps of Engineers, 1960). Some of the results presented here also were used in another Geological Survey report on the water resources of the basin (Parker and others, 1964).

The basic data used in the analyses are described first, and then the methods used in analyzing the flow-duration curves and low-flow frequency curves are discussed. A final section presents a method of estimating draft-storage relationships at ungaged sites, and tabulated results are consolidated at the end of the report.

\section{BASIC DATA FOR THE ANALYSES}

The basic data for the analyses presented in this report are the records of discharge collected at stream-gaging stations in the Delaware River basin and southern New Jersey. Streamflow records have been collected at over 130 sites in the area, but records from only 95 of these sites are used in the analyses. Records from the other sites are not used because either (1) only a short record had been collected, (2) the flow was regulated, or (3) the record tends to duplicate information obtained at 1 of the 95 sites.

The location of the 95 gaging stations used in the analyses is shown on figure 1; the names of the gaging stations are given in table 6 , and the station descriptions are given in a report on the compilation of records (U.S. Geol. Survey, 1960). Stations indicated as pivot stations on figure 1 have long-term records that are used to evaluate the frequency distribution of annual low flows. The indicated index stations generally have shorter records than do the pivot stations, but longer records than at most of the other stations shown on figure 1 .

A 40-year period ending in 1953 was used as a reference period because it was the longest period for which suitable records were available or could be estimated for the seven pivot stations. The reference period ends near the close of a 20-year period with a fairly consistent pattern of regulation from upstream reservoirs and before regulation and diversion for the New York City water supply began to affect streamflow in the Delaware River basin. To complete the records for the full reference period at the pivot stations, 14 months of discharge for station 74 (Perkiomen Creek at Graterford) were estimated by relation with station 86 (Brandywine Creek at Chadds Ford, Pa.), 15 years of record for station 58 (I,ehigh River at Bethlehem, Pa.) were adjusted for estimated inflow between an upstream and a downstream site, and 17 years of record for station 29 (Lackawaxen River at Hawley, Pa.) were estimated by relation with the 


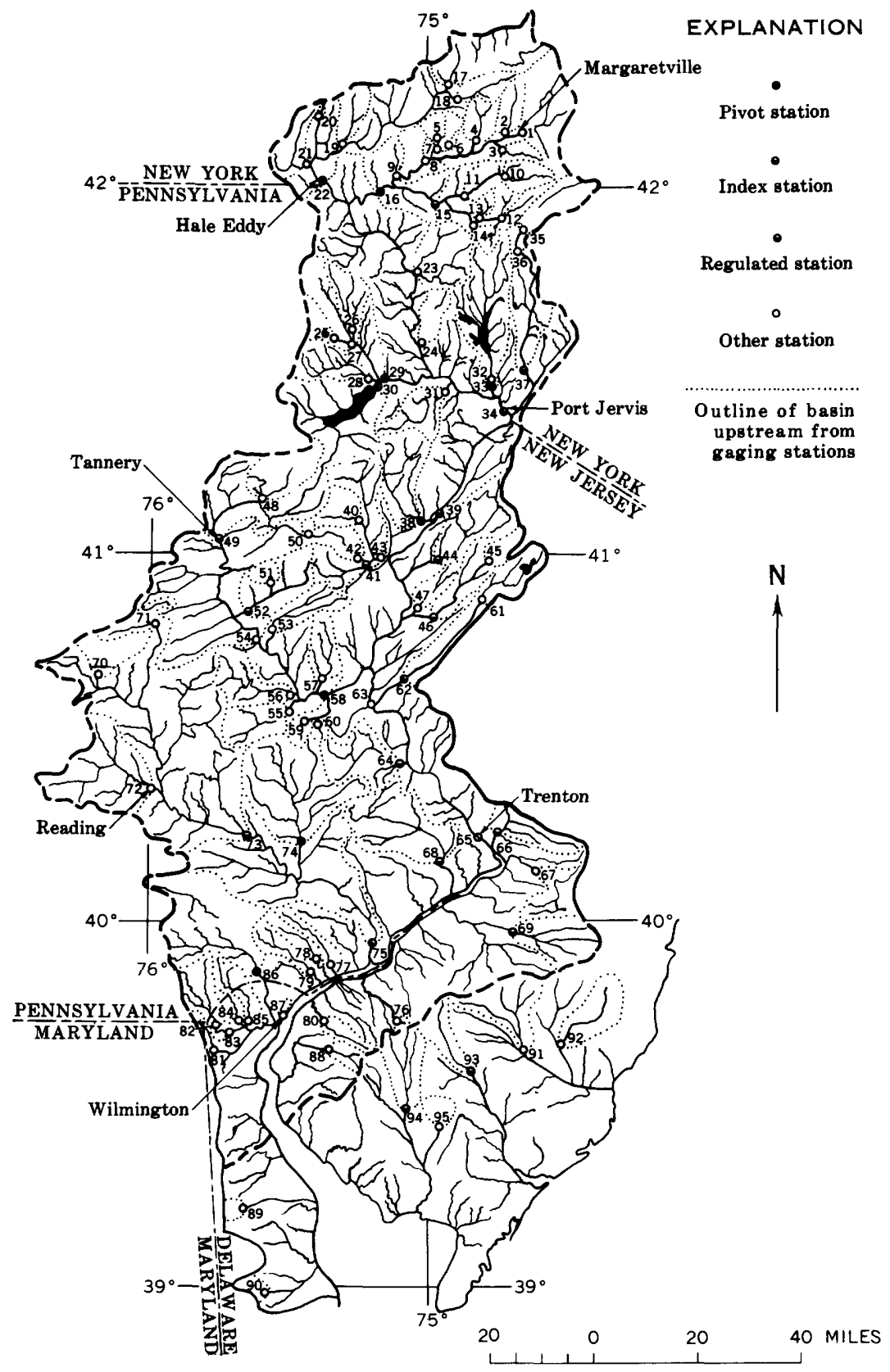

FIgorE 1.-Map of Delaware River basin showing location of stream-gaging stations and basin outlines. 
flow at the site of a former gaging station that had about 30 percent less drainage area. (Records for October 1918-December 1920 at the former station were computed for this report on the basis of gage heights, discharge measurements, weather records, and records for nearby stations.)

Annual low-flow summaries computed by electronic computer were used for all 7 pivot stations, 10 of the 15 index stations, and for the 6 regulated stations. These summaries give the lowest mean flow during each year for periods of $7,15,30,60,120$, and 183 consecutive days (table 1); they also give the number of days each year that the daily discharge fell between selected class limits (table 2). The annual low flows are the lowest flows in each climatic year starting

TABLE 1.-Annual low-flow data for station 7600 on Brandywine Creek at Chadds Ford, $P a$.

\begin{tabular}{|c|c|c|c|c|c|c|}
\hline \multirow{2}{*}{ Year } & \multicolumn{6}{|c|}{$\begin{array}{l}\text { Lowest mean discharge, in cubic feet per second, for indicated number of } \\
\text { consecutive days }\end{array}$} \\
\hline & 7 & 15 & 30 & 60 & 120 & 183 \\
\hline $\begin{array}{l}1912 \\
1913 \\
1914 \\
1916 \\
1916\end{array}$ & $\begin{array}{l}129.1 \\
134.6 \\
100.4 \\
166.0 \\
136.7\end{array}$ & $\begin{array}{l}135.5 \\
152.8 \\
104.3 \\
173.1 \\
146.9\end{array}$ & $\begin{array}{l}150.0 \\
167.9 \\
110.5 \\
205.7 \\
156.3\end{array}$ & $\begin{array}{l}197.4 \\
189.8 \\
115.9 \\
208.9 \\
168.3\end{array}$ & $\begin{array}{l}225.1 \\
222.1 \\
139.8 \\
247.8 \\
183.5\end{array}$ & $\begin{array}{l}253.8 \\
236.3 \\
195.3 \\
293.2 \\
232.8\end{array}$ \\
\hline $\begin{array}{l}1917 \\
1918 \\
1919 \\
1920 \\
1921\end{array}$ & $\begin{array}{r}122.7 \\
91.1 \\
147.1 \\
142.9 \\
77.7\end{array}$ & $\begin{array}{r}126.1 \\
94.6 \\
185.3 \\
145.4 \\
85.9\end{array}$ & $\begin{array}{r}136.5 \\
99.3 \\
231.4 \\
154.6 \\
92.1\end{array}$ & $\begin{array}{r}156.2 \\
104.4 \\
264.0 \\
178.6 \\
97.9\end{array}$ & $\begin{array}{l}193.4 \\
105.3 \\
345.2 \\
229.9 \\
117.7\end{array}$ & $\begin{array}{l}207.7 \\
115.8 \\
379.9 \\
264.6 \\
139.3\end{array}$ \\
\hline $\begin{array}{l}1922 \\
1923 \\
1924 \\
1926\end{array}$ & $\begin{array}{r}95.0 \\
99.7 \\
122.9 \\
77.4 \\
102.1\end{array}$ & $\begin{array}{r}97.2 \\
105.6 \\
130.7 \\
83.9 \\
124.9\end{array}$ & $\begin{array}{r}99.6 \\
113.5 \\
147.5 \\
100.6 \\
139.2\end{array}$ & $\begin{array}{l}101.6 \\
131.4 \\
188.4 \\
108.9 \\
164.7\end{array}$ & $\begin{array}{l}112.5 \\
153.1 \\
208.8 \\
131.8 \\
186.9\end{array}$ & $\begin{array}{l}140.5 \\
173.1 \\
250.2 \\
155.7 \\
205.3\end{array}$ \\
\hline $\begin{array}{l}1927-1928 \\
1929 \\
1930\end{array}$ & $\begin{array}{r}147.9 \\
198.6 \\
85.7 \\
66.7 \\
100.9\end{array}$ & $\begin{array}{r}156.3 \\
238.3 \\
97.1 \\
67.5 \\
104.6\end{array}$ & $\begin{array}{r}192.0 \\
252.8 \\
109.6 \\
71.1 \\
108.2\end{array}$ & $\begin{array}{r}232.0 \\
267.7 \\
137.3 \\
81.9 \\
111.7\end{array}$ & $\begin{array}{r}280.7 \\
289.7 \\
196.6 \\
91.0 \\
127.7\end{array}$ & $\begin{array}{l}324.4 \\
337.4 \\
232.4 \\
103.3 \\
175.3\end{array}$ \\
\hline $\begin{array}{l}1932 \\
1933 \\
1934 \\
1935\end{array}$ & \begin{tabular}{r|}
51.3 \\
178.3 \\
147.1 \\
164.1 \\
102.9
\end{tabular} & $\begin{array}{r}52.2 \\
199.9 \\
160.4 \\
186.4 \\
109.2\end{array}$ & $\begin{array}{r}57.9 \\
214.2 \\
205.6 \\
198.5 \\
115.1\end{array}$ & $\begin{array}{r}77.0 \\
258.0 \\
229.9 \\
243.3 \\
124.0\end{array}$ & $\begin{array}{l}102.2 \\
299.7 \\
261.3 \\
300.9 \\
135.9\end{array}$ & $\begin{array}{l}154.1 \\
354.8 \\
285.5 \\
326.8 \\
164.3\end{array}$ \\
\hline $\begin{array}{l}1937 \\
1938 \\
1939 \\
1941\end{array}$ & $\begin{array}{r}127.7 \\
213.6 \\
151.4 \\
122.7 \\
57.7\end{array}$ & $\begin{array}{r}129.5 \\
219.9 \\
154.8 \\
129.6 \\
58.9\end{array}$ & $\begin{array}{r}131.7 \\
246.3 \\
167.9 \\
146.4 \\
63.6\end{array}$ & $\begin{array}{r}187.8 \\
275.4 \\
182.3 \\
168.0 \\
71.2\end{array}$ & $\begin{array}{r}199.9 \\
344.2 \\
207.8 \\
194.2 \\
87.9\end{array}$ & $\begin{array}{l}262.2 \\
375.7 \\
230.4 \\
246.2 \\
104.1\end{array}$ \\
\hline $\begin{array}{l}1942 \\
1943 \\
1944 \\
1946\end{array}$ & $\begin{array}{r}105.7 \\
75.1 \\
57.3 \\
190.9 \\
157.9\end{array}$ & $\begin{array}{r}110.9 \\
76.0 \\
58.7 \\
205.0 \\
164.5\end{array}$ & $\begin{array}{r}149.4 \\
83.0 \\
65.3 \\
218.7 \\
168.5\end{array}$ & $\begin{array}{r}159.6 \\
99.8 \\
94.7 \\
254.4 \\
183.8\end{array}$ & $\begin{array}{l}219.7 \\
147.1 \\
130.6 \\
322.6 \\
214.0\end{array}$ & $\begin{array}{l}305.3 \\
197.1 \\
157.3 \\
351.3 \\
239.0\end{array}$ \\
\hline $\begin{array}{l}1947 \\
1948 \\
1949 \\
1950 \\
1952\end{array}$ & $\begin{array}{r}102.0 \\
201.9 \\
111.4 \\
145.6 \\
94.1 \\
167.9\end{array}$ & $\begin{array}{r}104.6 \\
212.1 \\
114.2 \\
148.3 \\
98.3 \\
173.2\end{array}$ & $\begin{array}{l}108.0 \\
229.0 \\
121.8 \\
179.5 \\
111.3 \\
178.1\end{array}$ & $\begin{array}{l}133.8 \\
251.5 \\
126.6 \\
217.9 \\
119.8 \\
200.2\end{array}$ & $\begin{array}{l}182.8 \\
332.2 \\
134.6 \\
245.0 \\
160.3 \\
281.4\end{array}$ & $\begin{array}{l}244.1 \\
383.1 \\
163.6 \\
273.6 \\
224.0 \\
390.5\end{array}$ \\
\hline
\end{tabular}


April 1 and ending the following March 31; thus, the low-flow periods in fall and winter are considered in the same year as the low flows of the preceding summer. The segregation by class limits that was used to compute the flow-duration curves is for water years ending September 30. Therefore, in this report, the reference period for the annual low flows is April 1, 1913-March 31, 1953 (climatic years 1913-52), and the reference period for the flow-duration curves is October 1, 1913-September 30, 1953 (water years 1914-53).

For the other 72 gaging stations used in this report, the lowest 7 and 30-day discharges for each year were computed manually from the records of daily discharge. Records for these'stations were analyzed only to the extent of obtaining indices of annual low flow, except for station 15 (Beaver Kill at Cooks Falls, N.Y.) and station 39 (Flat Brook near Flatbrookville, N.J.) for which the annual low flows for the other lengths of period were also computed manually.

Annual low flows for 274-day periods were computed from the monthly mean discharge for the 7 pivot stations and 12 index stations for which annual low-flow data for periods of 183 consecutive days were available. The lowest 9 -month average was used for convenience even though the average for the lowest 274 -day period would have been somewhat lower. Also, each 9 -month period used was restricted to a single climatic year beginning April 1 even though a lower 9 -month period could have been obtained by using a few months from the preceding year or the following year.

Annual low flows for 365-day periods for the seven pivot stations and one index station were computed from monthly mean discharge by a method that allowed 2 months overlap in computing the average for independent periods. The lowest 12-month average of the entire record was assigned order number 1 , and the second lowest 12-month average, which could include no more than two of the months used in the a verage for the lower order number, was assigned order number 2. This process was repeated to obtain the minimum 365-day discharge for successively higher order numbers. The minimum discharge for 365 consecutive days is actually less than that for 12 consecutive months, but the difference is probably small compared with the difference that would be introduced by a change in the arbitrary amount of overlap allowed in selecting independent events. 


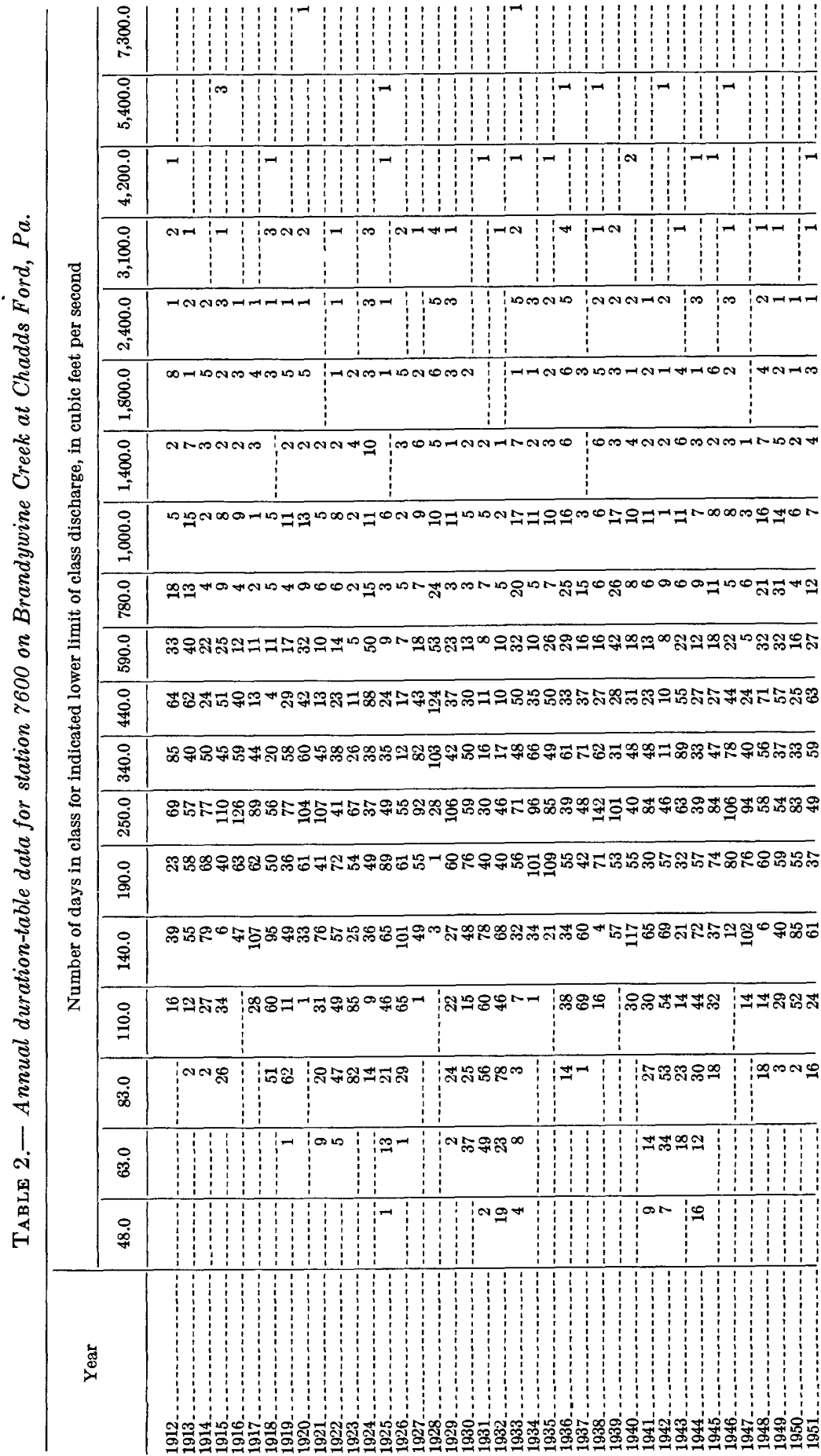


STREAMS, DELAWARE RIVER BASIN, SOUTHERN NEW JERSEY N7

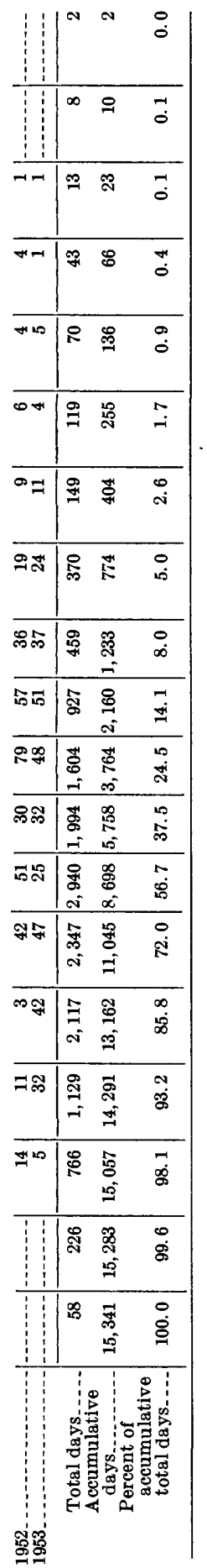




\section{FLOW-DURATION CURVES}

The flow-duration curves for each long-term station were smoothed by comparison with the flow-duration curves for other long-term stations, and the flow-duration curves for several short-term stations were extended to the reference period October 1913-September 1953 by relation with one or more long-term stations. The smoothing of the curves for the long-term stations amounted to changes of only a few percent, as illustrated by the observed flow-duration data for stations 16 and 86 plotted on figures 2 and 3 ; but the extending of the short-term records produced an appreciable change in some of the curves, as illustrated by the observed flow-duration data for the period 1936-53 at station 64 plotted on figure 3. The flow-duration curves were extended by use of a relation based on discharge of equal percent duration at pairs of gaging stations, following the method described by Searcy $(1959$, p. 14 17).

For regulated stations, the flow-duration curves for the regulated part of the record were extended to the reference period to represent what the flow would have been had the same pattern of regulation affected the flow during the entire reference period. For regulated stations that had a considerable record before regulation started, flow duration curves for the unregulated part of the record were extended to the reference period to represent what the flow would have been without regulation.

The results of the flow-duration-curve analysis are presented in tables 3 and 4 and on figures 2-5. In table 3 the discharge is expressed in million gallons per day per square mile for only those stations with unregulated flow; the results in table 4 are expressed in cubic feet per second for both regulated and unregulated flow.

The flow-duration curves plotted in figures 2 and 3 for 17 stations show considerable similarity in shape. The most outstanding exception is the curve for station 64, Tohickon Creek at Pipersville, Pa., which is unusually steep. The two curves with the flattest slope are those for stations 69 and 94 , which are on streams that drain from the Coastal Plain area in New Jersey. Flow-duration data for stations 41 and 66 were omitted from table 3 because of the possible effect of regulation by mills and hydro-power plants, but the plotting of the duration curves for these stations on figures 2 and 3 indicates that any such effect is probably minor.

The curves for six regulated stations are shown in figure 4, and those for regulated conditions at two of these stations are compared with curves for natural conditions in figure 5. Duration curves for regulated conditions are applicable only so long as the pattern of regulation remains the same as that during the period on which the 
curves are based. New sources of regulation or a change in the type of regulation from an existing development would alter the flow-duration curves.

\section{LOW-FLOW FREQUENCY CURVES}

All the low-flow frequency curves presented in this report have been adjusted to the reference period April 1913-March 1953 (climatic years 1913-52). In addition, the curves for each long-term station have been smoothed by comparison with the low-flow frequency data for other long-term stations. The results are listed in tables 5 and 6 and are illustrated in figure 7.

The distribution of annual low flow at each of the seven long-term stations in the basin (shown as pivot stations on fig. 1) and one longterm station outside the basin (Monocacy River near Frederick, Md.) was compared with that at two or more other long-term stations and smoothed as described in the next few paragraphs. Because each of these stations was in turn used as the center of a group of stations, they are called pivot stations in this report. They are also pivotal in that they are the critical stations on which the analyses for all other stations in the basin depend.

The smoothing of the frequency distribution of annual low flow at the seven pivot stations was accomplished by plotting arrayed annual minimum discharge at pairs of pivot stations on logarithmic paper, as in figure 6. The lowest 7-day discharge at one of the stations during the period 1913-52 was plotted against the lowest 7-day discharge at the other stations, and then the second lowest 7-day annual minimum was plotted against the second lowest at the other station and so on until the highest of the 7-day annual minimums at each station were plotted against each other. Similar plots were made of the arrayed annual minimum flow for periods of progressively greater length, such as the 15-day and 30-day periods. Lines of relation were drawn to average the plotted points for each length of period, with some consideration being given to the slope and position of the relation lines for the other length periods. For most of the relations, the lines for the different periods tend to converge at high discharges.

Lines of relation such as those illustrated in figure 6 were used to transpose low-flow frequency experience from one pivot station to another. The transposed data for each order number was averaged with the observed data at the station and used to define the low-flow frequency curves shown in figure 7. Smoothing the low-flow frequency curves by this method results in curves that average the observed data (solid circles in figure 7), but which depart considerably from individual points or groups of points. 


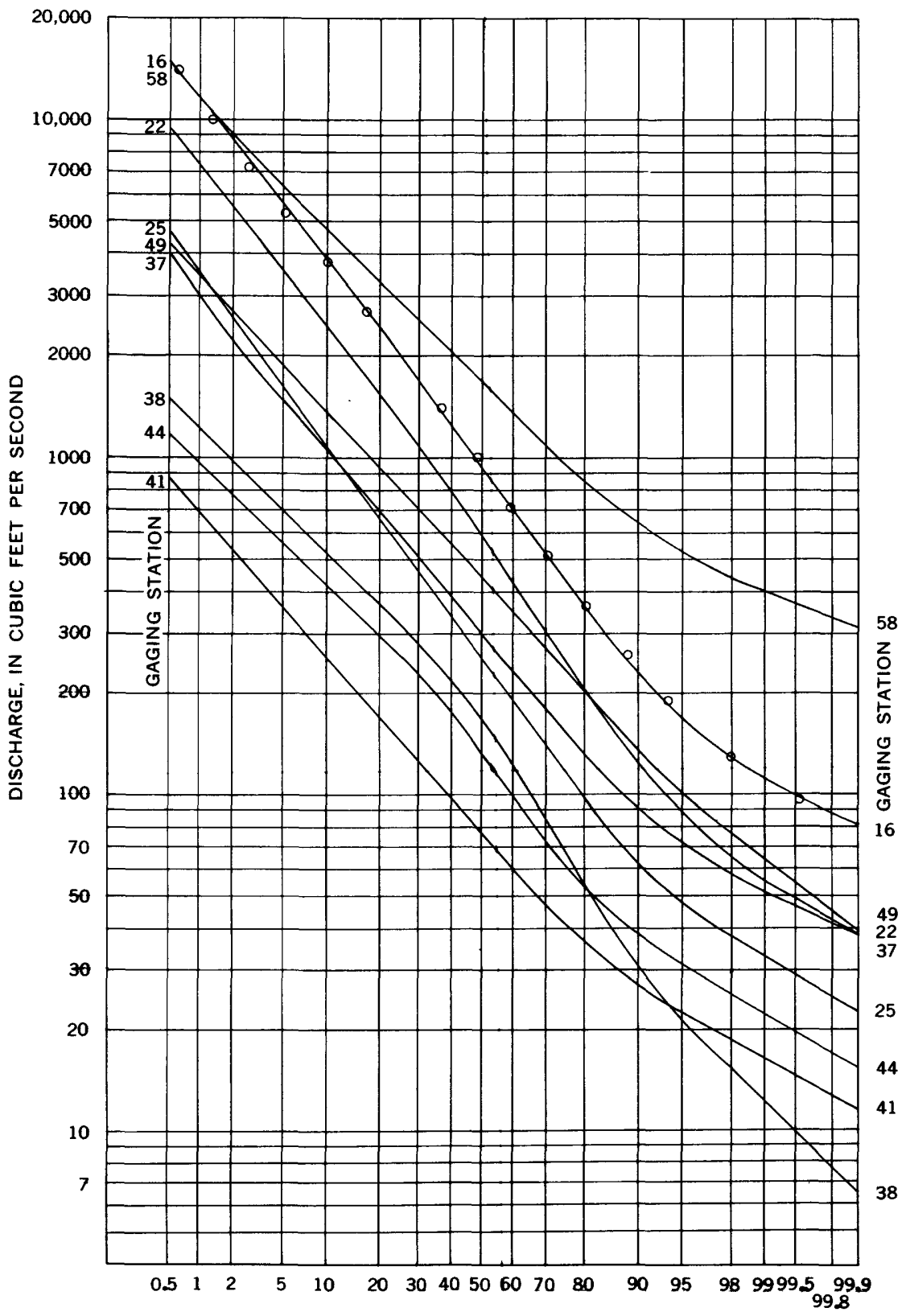

PERCENT OF TIME DAILY DISCHARGE EQUALED OR EXCEEDED THAT SHOWN

Figure 2.-Flow-duration curves for nine stream-gaging stations in the upper part of Delaware River basin. Data adjusted to period October 1, 1913-September 30, 1953, on basis of long-term stream-flow records. Circles represent data from observed records 1914-53 for station 16. 
The plotting of the four lowest points for the 120-day discharge in figure 6 (four lowest squares) demonstrates the need for smoothing the observed data. It is obvious from the way these four points plot that either the lowest 120-day flow observed at the Chadds Ford station is unusually high or that the lowest at the Graterford station is unusually low. The relation line is drawn to express this interpretation so that when the experience at one of the stations is transposed through this relation and averaged with the observed flow at the other station the answer is a compromise of the experience at both stations. (In this example, the transposed discharge is $65 \mathrm{cfs}$ (cubic feet per second).) It is for this reason that the curve for the 120-day period at the 40-year recurrence interval in figure 7 is considerably lower than the observed discharge of $88 \mathrm{cfs}$.

The lower end of the smoothed frequency curves for Brandywine Creek at Chadds Ford was verified by comparison with annual low flows for a 68-year period on Perkiomen Creek at Graterford, Pa., the longest record in the Delaware River basin. The 7- and 183-day annual low flows for the period 1885-1952 at the Graterford station, transposed to the Chadds Ford station by the curves of relation shown in figure 6, are shown on figure 7 . They are plotted one log cycle higher than the family of curves and are shown for comparison with smoothed curves for 7 and 183 days that also have been raised one $\log$ cycle. The data for the longer period (plotted as circles) average about 5 percent higher than the smoothed curves, although the slope and shape are essentially the same. Annual low-flow frequency curves for 57 years of record on the Monocacy River near Frederick, Md., have also been transposed to the Chadds Ford station (fig. 7) and provide a further verification of the lower end of the smoothed frequency curves.

The relation lines shown in figure 6 reflect differences in flow characteristics that are due to differences in topography, geology, and climate, not to variation in the chance occurrence of hydrologic events. Comversely, the transposed data represent an array of annual low flows that would have occurred had the sequence of hydrologic events been reversed in two basins. Use of the combination of

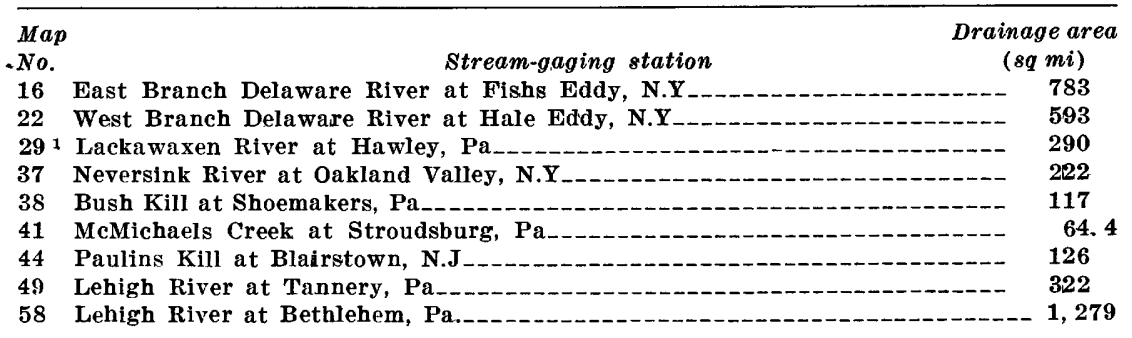

\footnotetext{
1 Shown as No. 25 in figure 2.
} 


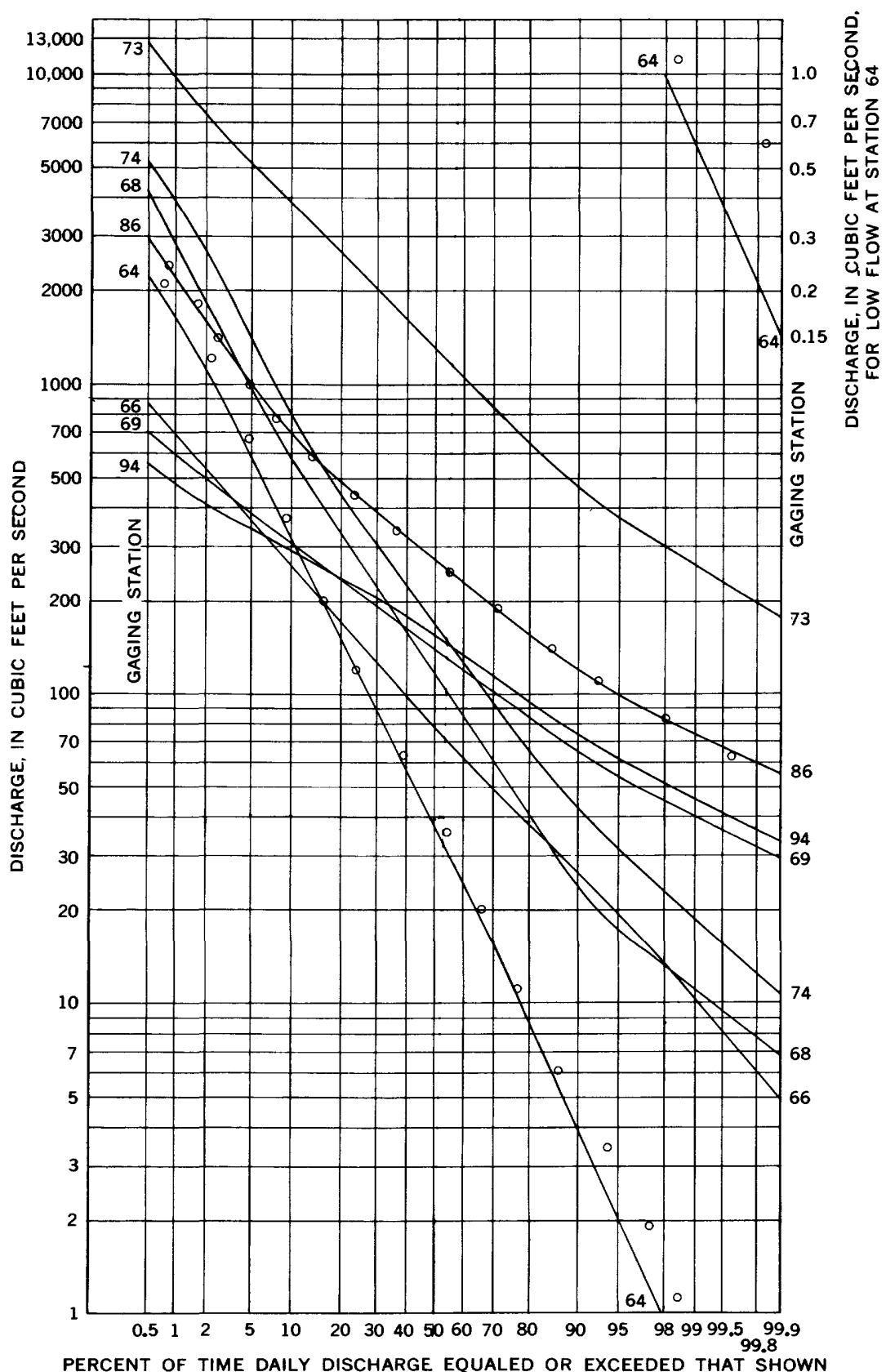

Figure 3.-Flow-duration curves for eight stream-gaging stations in the lower part of Delaware River basin. Data adjusted to period October 1, 1913-September 30, 1953, on basis of long-term stream-flow records. Circles represent data from observed records 1914-53 for station 86 and 1936-53 for station 64 . 
transposed and observed data helps to smooth the low-flow frequency curves more satisfactorily than would be possible using only the observed data. If the relation curve is drawn through the mean of the points for a given period of days, the use of this method affects only the shape of the frequency curve, not its position at the 2-year recurrence interval. A further smoothing of the curves is made by considering the shape and slope of the data for the other low-flow periods when the curves are drawn on graph paper as in figure 7 .

Low-flow frequency curves for the 15 index stations were extended by relating the annual low flows to the annual low flows at one or more pivot stations for the concurrent period of record (pl. 1) ; relation curves for stations 46, 52, and 93 were drawn for the 7-and 30-day annual low flows only. Relation lines thus drawn were used to transpose the smoothed low-flow frequency curves from the pivot stations to the index stations by assuming that the relation curves were the same as those that would have been defined by records for the full reference period. Even though the relation lines on plate 1 are actually but an estimate of the long-term position, they can be used to obtain a better approximation of the low-flow frequency curves for the period 1913-52 than could be obtained by an analysis of only the observed data for 1936-52.

The arrayed data shown on plate 1 are plotted in the same manner as in figure 6 , but the relation curves are not used merely to smooth the low-flow frequency data; they are used to extend them. Therefore, there must be some correlation between the annual low flows at the two stations if the procedure is to result in an improved estimate. The coefficient of correlation for each relation between a pivot station and an index station was estimated graphically by plotting the 7-day annual low flows for concurrent years as shown in the right half of plate 1. The relations shown in the left half were used only when the coefficient of correlation was greater than 0.70 .

One of the reasons for requiring at least a minimum degree of correlation is that the relation line defined by the arrayed data is unregressed. The regressed line of relation computed by the least-squares method is also shown in the right half of plate 1 for comparison.

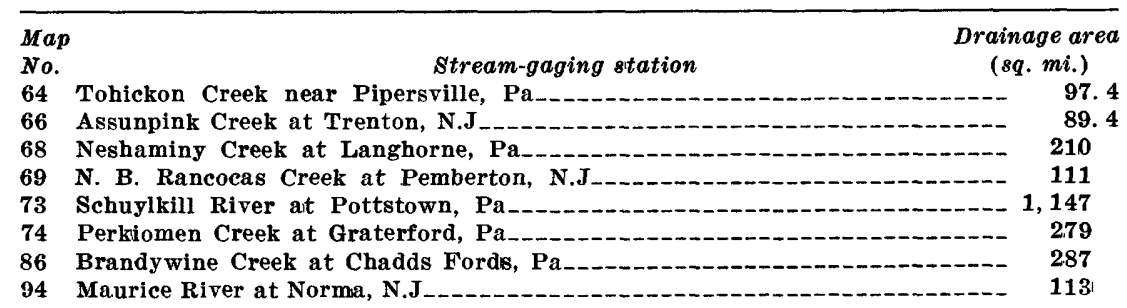

$696-5740-63-3$ 


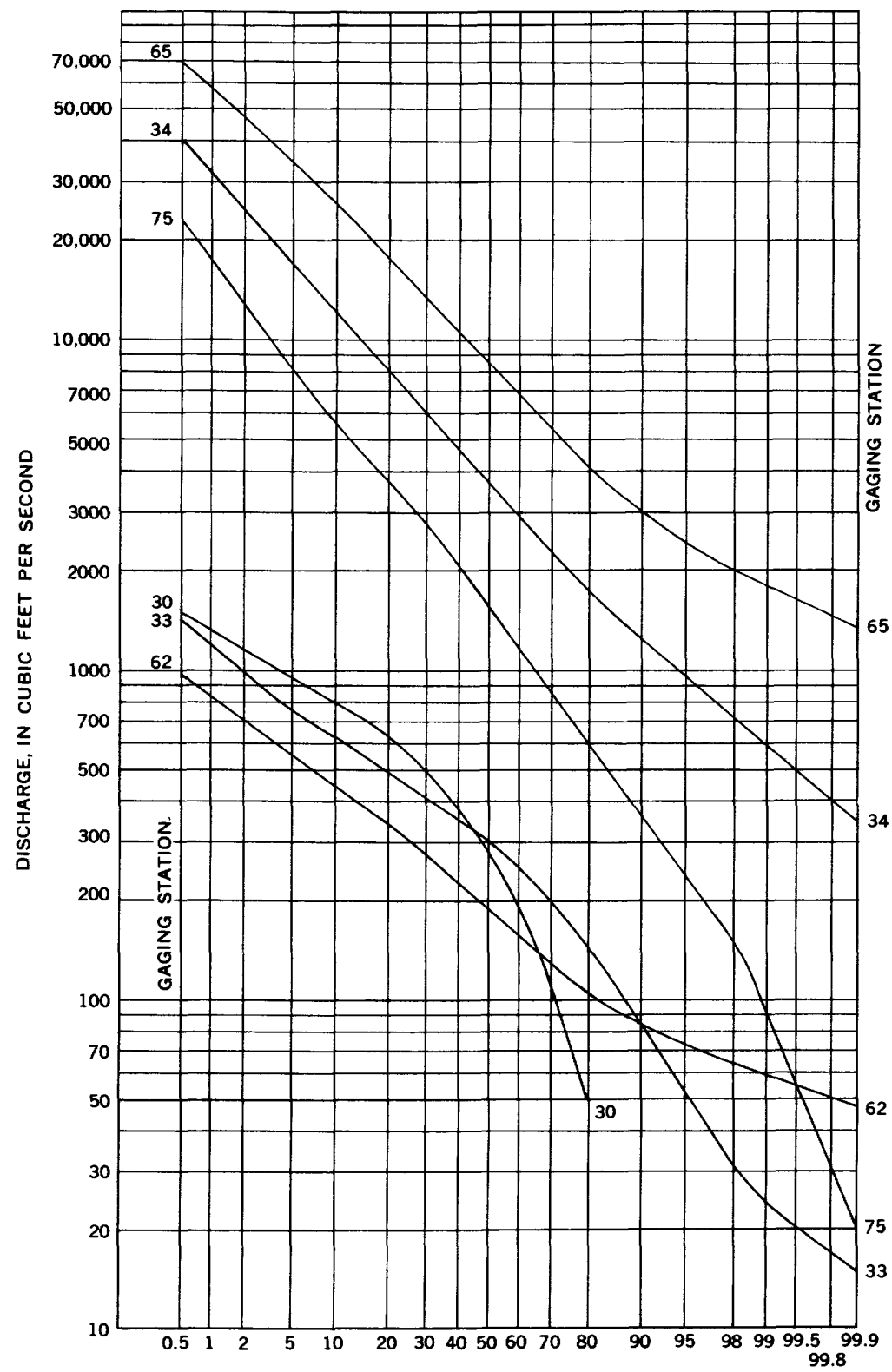

PERCENT OF TIME DAILY DISCHARGE EQUALED OR EXCEEDED THAT SHOWN

Figure 4.-Flow-duration curves for six stream-gaging stations affected by regulation and diversion in Delaware River basin. Duration curves are basedi on the pattern of regulation during the period of regulated record and are adjusted to the period October 1, 1913-September 30, 1953, on the basis of long-term streamflow records. 
The use of this line would tend to give a flatter low-flow frequency curve than would the unregressed line. Theoretically, neither the regressed nor the unregressed line give the correct result without adjustment. When the coefficient of correlation is greater than 0.7 , however, the use of the unregressed line, even without adjustment, gives low-flow frequency curves that are more reliable than those based only on the observed record.

Unregressed lines of relation were used to extend the low-flow frequency curves for most of the index stations, and the results are summarized in tables 5 and 6 . Indices of low flow for the other stations listed in table 6 were obtained by similarly relating their 7- and 30day annual low flows to those of an index station or pivot station. Some of the relations were so good that satisfactory estimates could be made from a relation based on only 4 years of overlapping record. The indices of natural low flow for station 52 (Pohopoco Creek near Parryville, $\mathrm{Pa}$.) that are shown in table 6 were obtained by relating the regulated annual minimums to the annual minimums adjusted for storage and diversion.

The discharge given for the 20-year recurrence interval in table 6 is an indication of the flow available without storage. A little storage would be required to develop the minimum 7-day flow shown in the table, and a little more would be required to develop the 30 -day flow; but the amount required could probably be provided by storage in the stream channel near the intake.

The ratio of the 7-day discharge at the 20-year recurrence interval to that at the 2-year recurrence interval is shown in table 6 for possible use in hydrologic studies. The ratio averages about 0.50 and ranges from 0.25 to 0.79 . The adjusted ratio is the observed ratio divided by the formula $1.53 Q_{2}{ }^{0.19}$ to adjust for the effect of difference in the median annual low flow per square mile $\left(Q_{2}\right)$. The coefficient of correlation of the relation between median annual low flow and the observed ratio is 0.58 , and the standard error of estimate is about 18 percent.

The low flow at seven of the stations listed in table 5 was affected by regulation during part of the reference period 1913-52. For two of these stations (stations 30 and 34 ), enough record was available from before regulation to permit an estimate of the preregulation low-flow

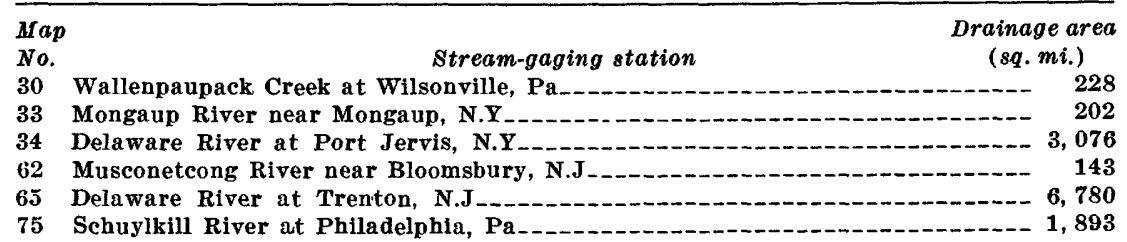




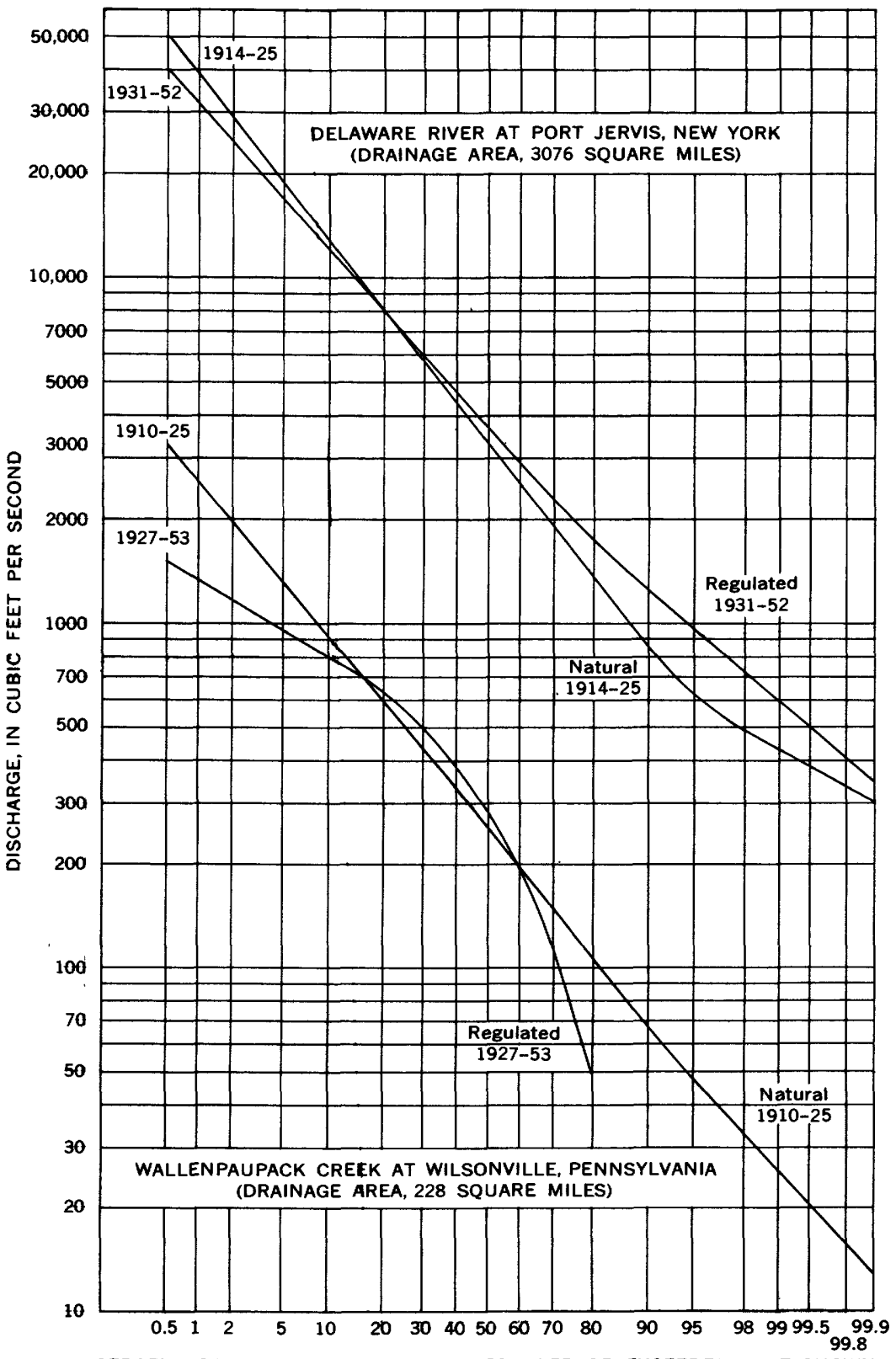

PERCENT OF TIME DAILY DISCHARGE EQUALED OR EXCEEDED THAT SHOWN

Figure 5.-Effect of regulation and diversion on flow-duration curves for Delaware River at Port Jervis, N.Y., and Wallenpaupack Creek at Wilsonville, Pa. Duration curves adjusted to period October 1, 1913-September 30, 1953, on basis of records for periods shown and records at long-term stations; curves for regulated condition presuppose same pattern of regulation as that for period shown. 
characteristics. For the other five stations, the results represent the low-flow frequency for the pattern of regulation that occurred during the correlation period adjusted to the hydrologic conditions during the reference period. The results for regulated conditions are shown only in cubic feet per second, as discharge per square mile would have little significance. Annual low flows for periods of 7 or more consecutive days at stations 41 and 66 were assumed to be free from the effects of regulation even though the daily discharge used in the flow duration analysis may have been affected. The flow at some of the other stations shown in table 5 has become regulated since 1953. Low-flow frequency data for three regulated stations (stations 61, 63, and 71) in addition to the seven listed in table 5 are listed in table 6 .

\section{STORAGE-REQUIRED FREQUENCY CURVES}

The storage-required frequency curves presented in this report show the frequency with which storage equal to or greater than selected amounts would be required to maintain selected rates of regulated flow. The curves, which were computed from the low-flow frequency curves previously discussed, are summarized in table 7 and are plotted on figures 8 and 9 . The frequency with which given amounts of storage is required provides a basis for obtaining an economic balance between the cost of the storage and the loss caused by an insufficient supply.

Comparison of the draft-storage curves on figures 8 and 9 shows that on a per-square-mile basis there is less variation in storage required between stations in the upper part of the Delaware River basin than in the lower part. For a storage required of 20 million gallons per square mile at a recurrence interval of 10 years, the spread in draft rate at 11 stations in the upper part of the basin is only about 50 percent as compared to a more than twofold spread among 8 stations in the lower part.

The storage-required computations used in this report are based on frequency-mass curves such as that shown in figure 10. The curved line in this figure is based on discharge data taken from the low-flow frequency curves. The volume of discharge for the 60-day period, for example, was obtained by multiplying the 60-day discharge for a 10 year recurrence interval at station 15 (table 5 ) (0.172 mgd per sq mi) by 60 days to obtain 10.3 million gallons per square mile. Similar computations for other periods of consecutive days provide the data needed to define the frequency-mass curve. Draft rates for selected amounts of storage were computed as shown in figure 10 and were plotted on frequency curves such as those in figure 11. 


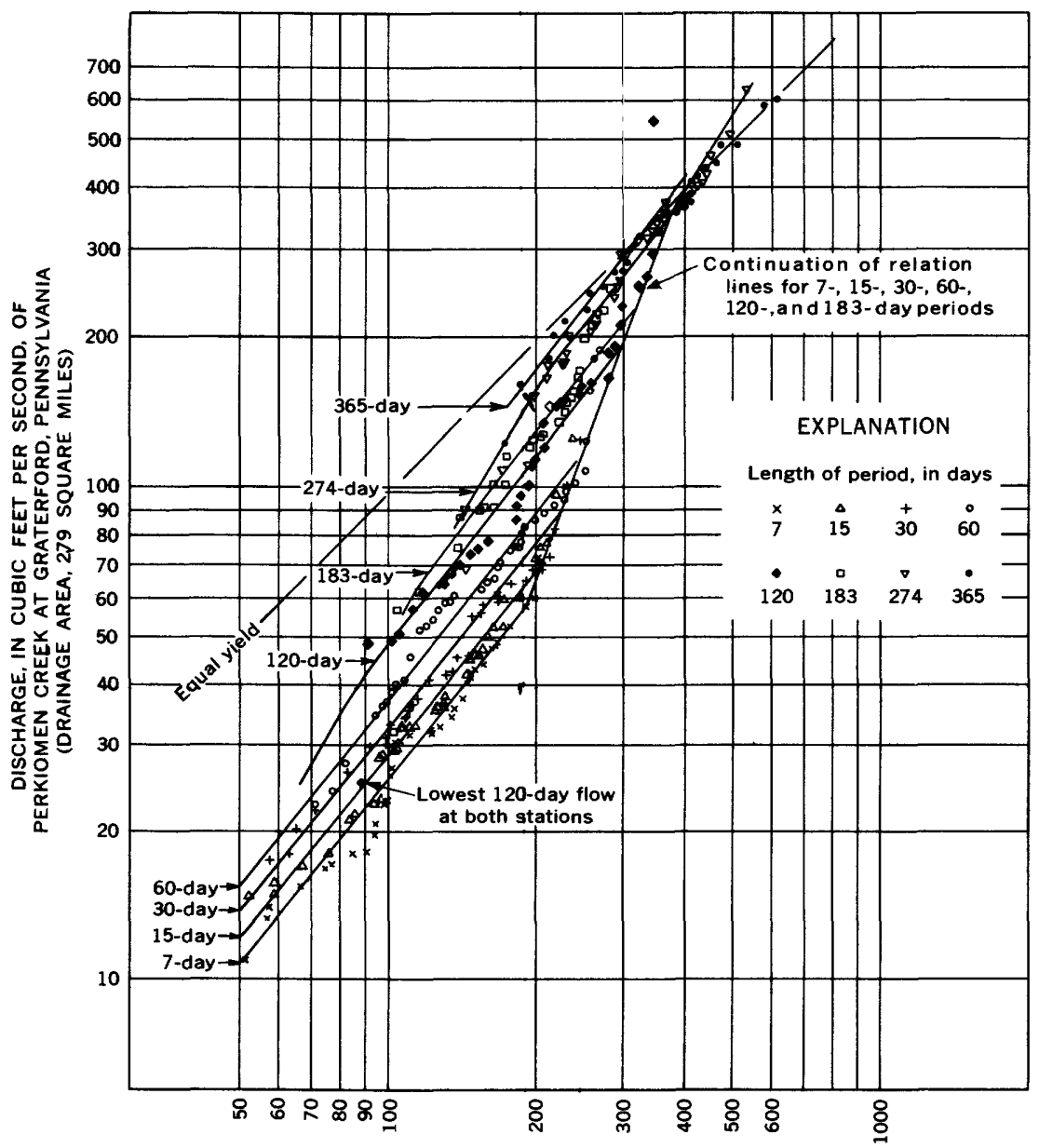

DISCHARGE, IN CUBIC FEET PER SECOND, OF BRANDYWINE CREEK AT CHADDS FORD, PENNSYLVANIA (DRAINAGE AREA, 287 SQ MI)

Frguro 6.-Relation of arrayed annual minimum discharge at two pivot stations in Delaware River basin, 1913-52.

Storage-required frequency curves were computed for all stations for which the low-flow frequency curves had been computed beyond the 30-day period, except for the six regulated stations. Thus, storagerequired curves are given for all 7 of the pivot stations (fig. 1) and for 12 of the 15 index stations.

The method used in this report for obtaining storage required neglects the loss due to evaporation and seepage from the reservoir that would be needed to provide the storage, and it neglects a bias of about 10 percent that results from the use of the frequency-mass curve. All the neglected factors tend to make the computed amount of required 
storage smaller than it should be. Therefore, the storage-required figures presented in this report would have to be increased before being used in a final design. They may be used, however, for reconnaissance planning and for comparison between stations.

The bias in the use of the frequency-mass curve arises from assuming that a critical period of definite length can be assigned to each draft rate and recurrence interval. Under actual conditions, however, the length of the critical period for a given draft rate and recurrence interval varies about the average value for that draft rate and recurrence interval. In figure 10, for example, the critical period (length of time to maximum drawdown) for a draft of $0.50 \mathrm{mgd}$ per sq $\mathrm{mi}$ at a recurrence interval of 10 years is 129 days. If the amount of storage required each year were computed from yearly mass curves, however, the length of the critical period for a 10-year recurrence interval would very likely differ somewhat from 129 days, and this difference would cause the amount of storage required to be greater than that for 129 days.

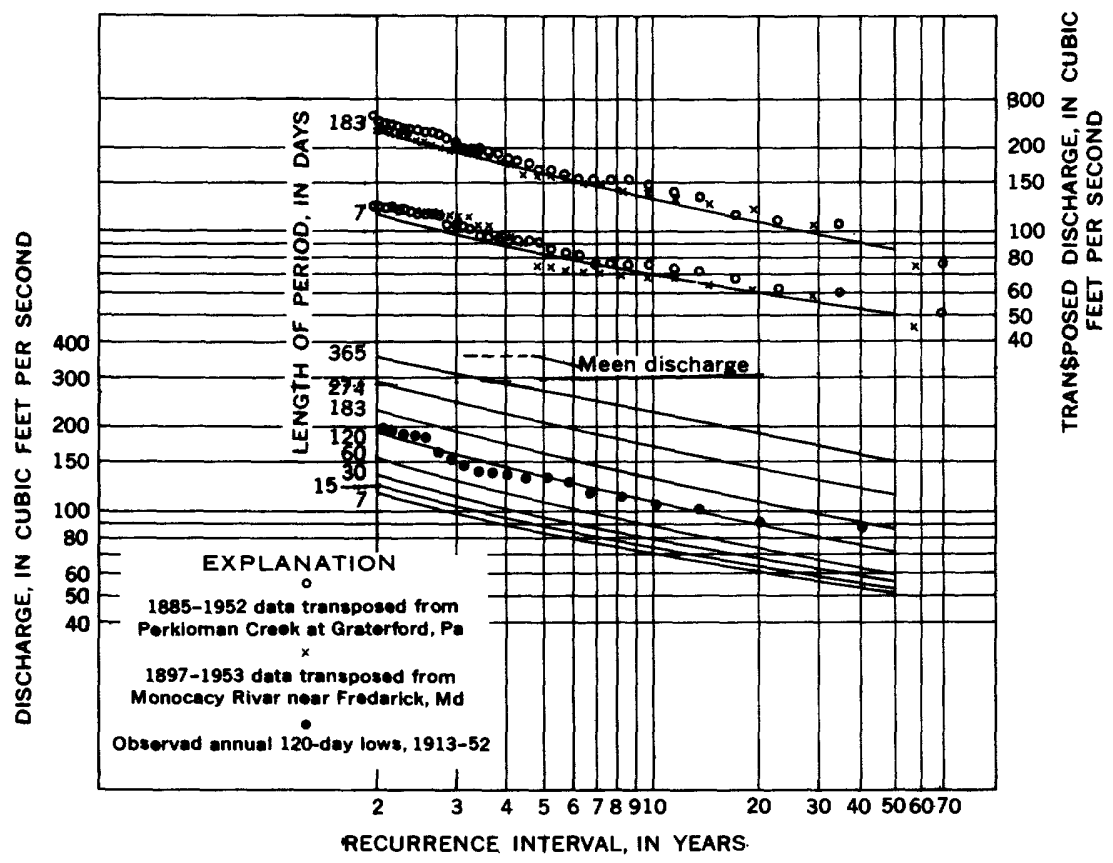

Figdre 7.-Low-flow frequency curves for Brandywine Creek at Chadds Ford, Pa., 1913-52. Curves represent distribution of annual minimum flows for indicated lengths of perfod. 
N20 CONTRIBUTIONS TO THE HYDROLOGY OF THE UNITED STATES

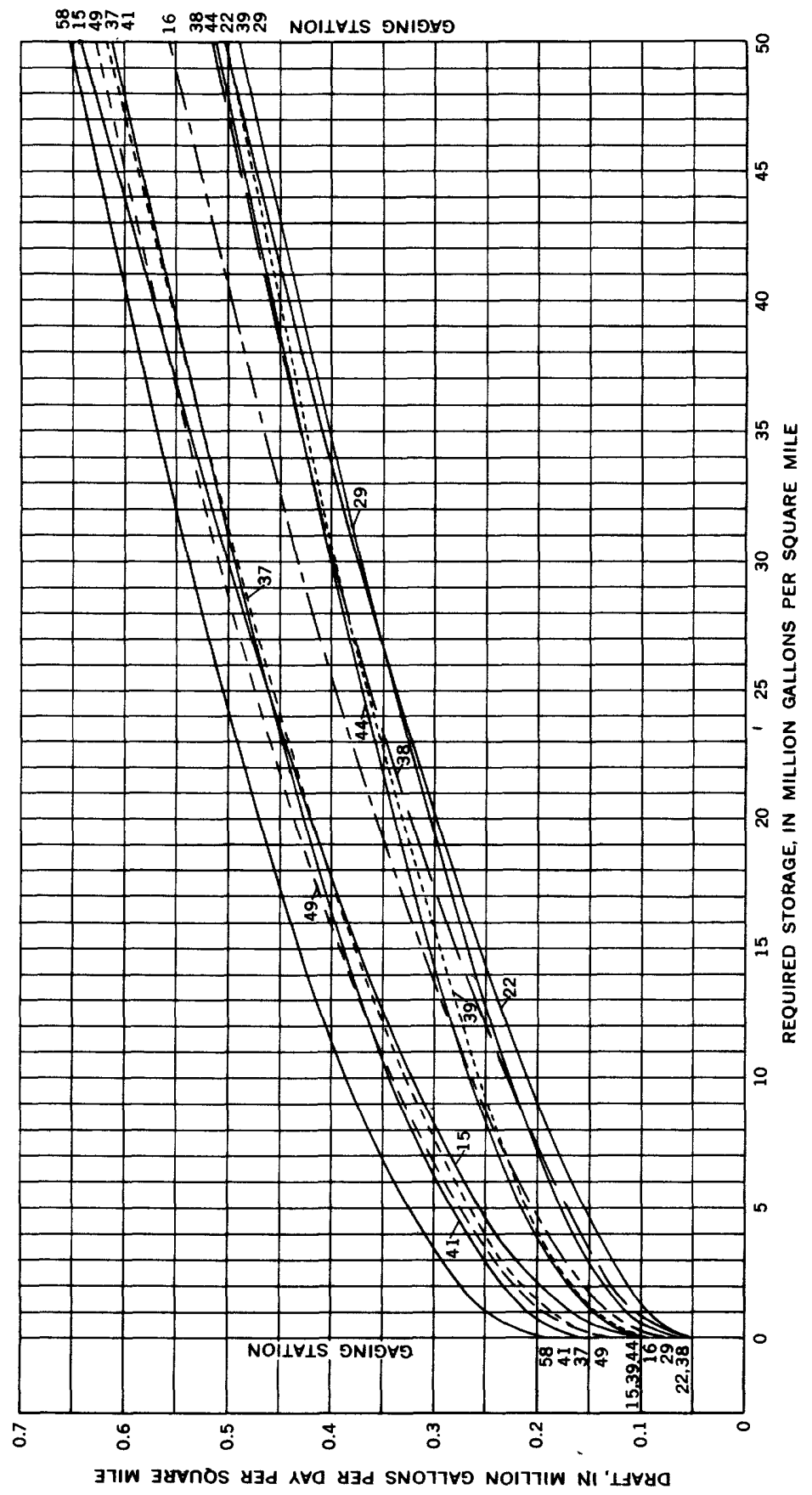


STREAMS, DELAWARE RIVER BASIN, SOUTHERN NEW JERSEY N21

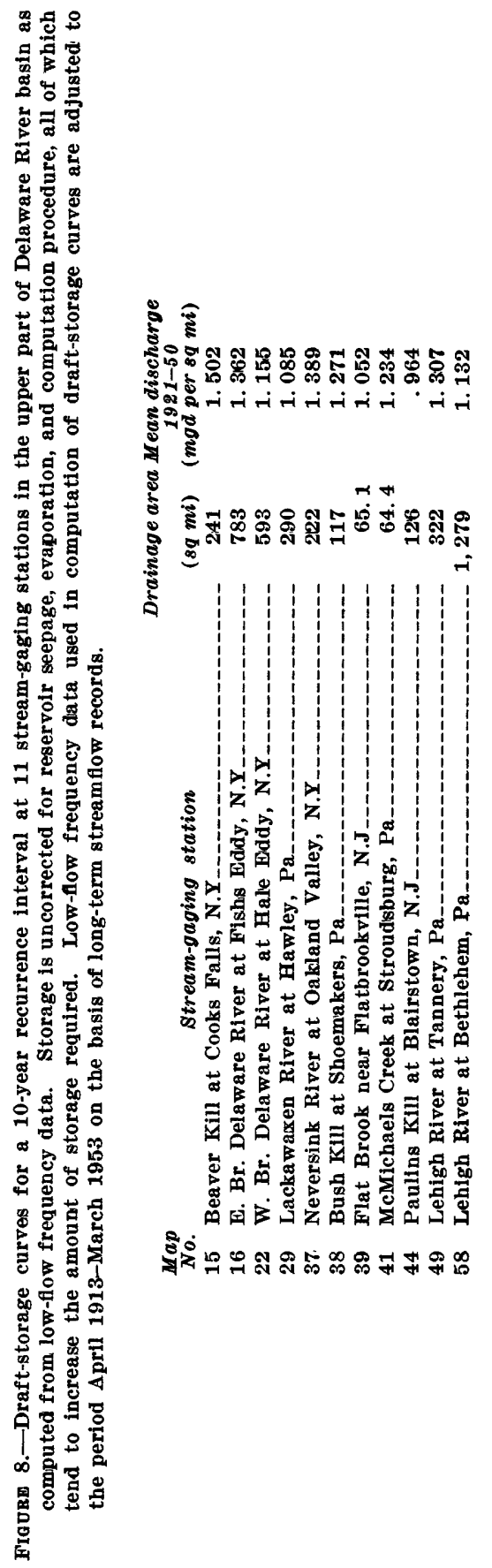




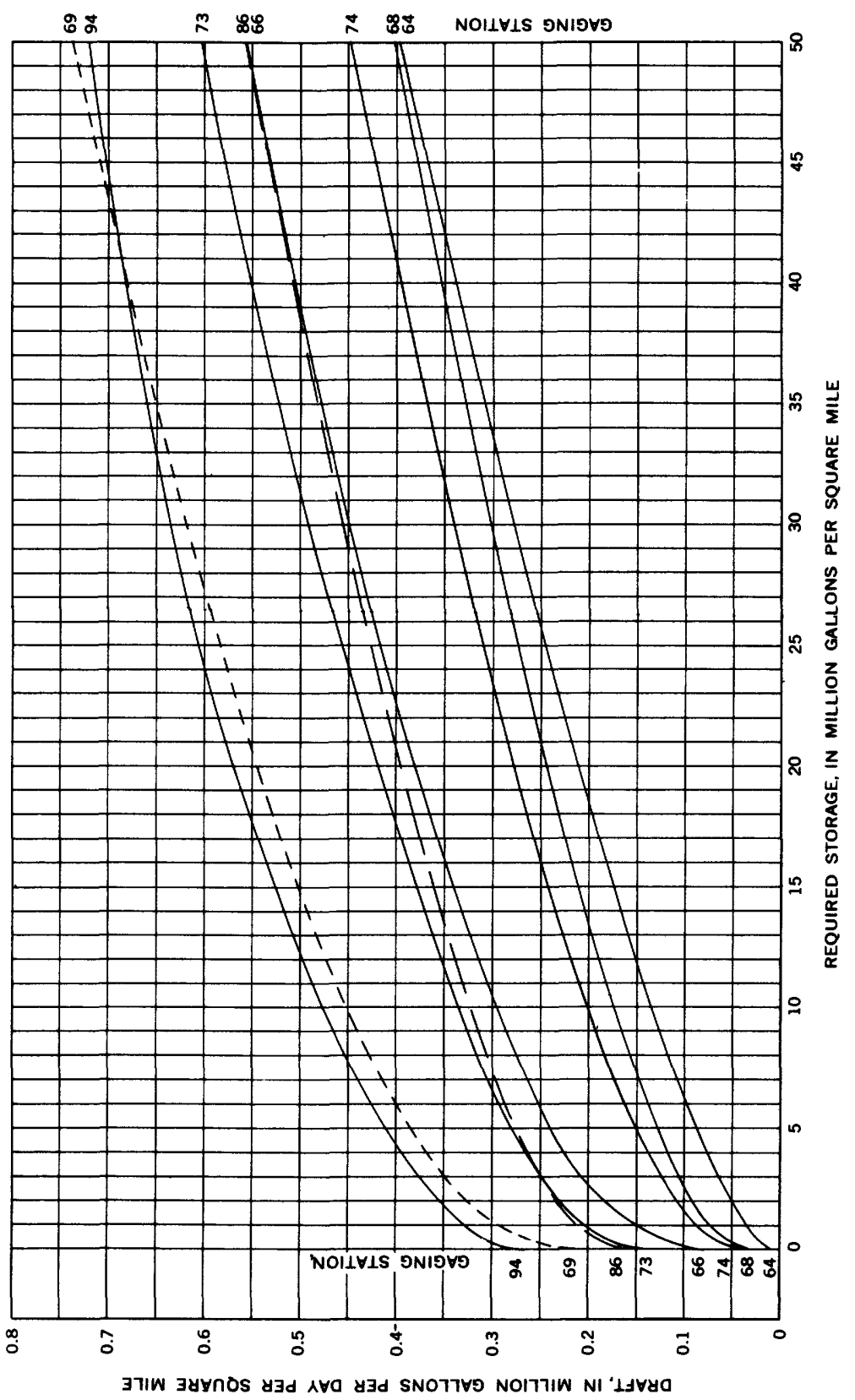


STREAMS, DELAWARE RIVER BASIN, SOUTHERN NEW JERSEY N23

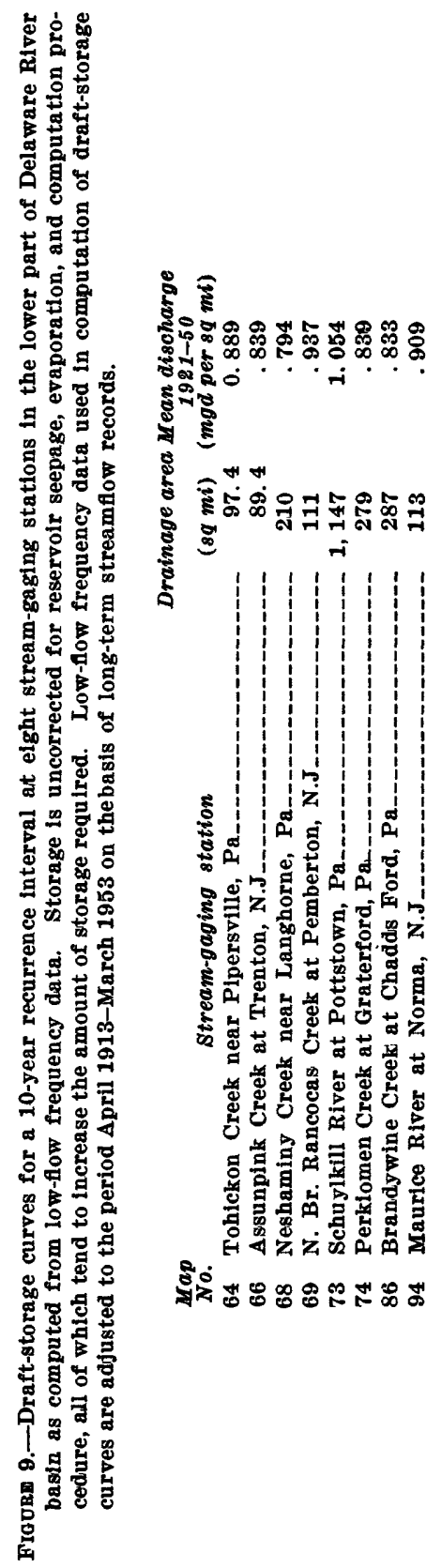


LENGTH OF PERIOD, IN DAYS

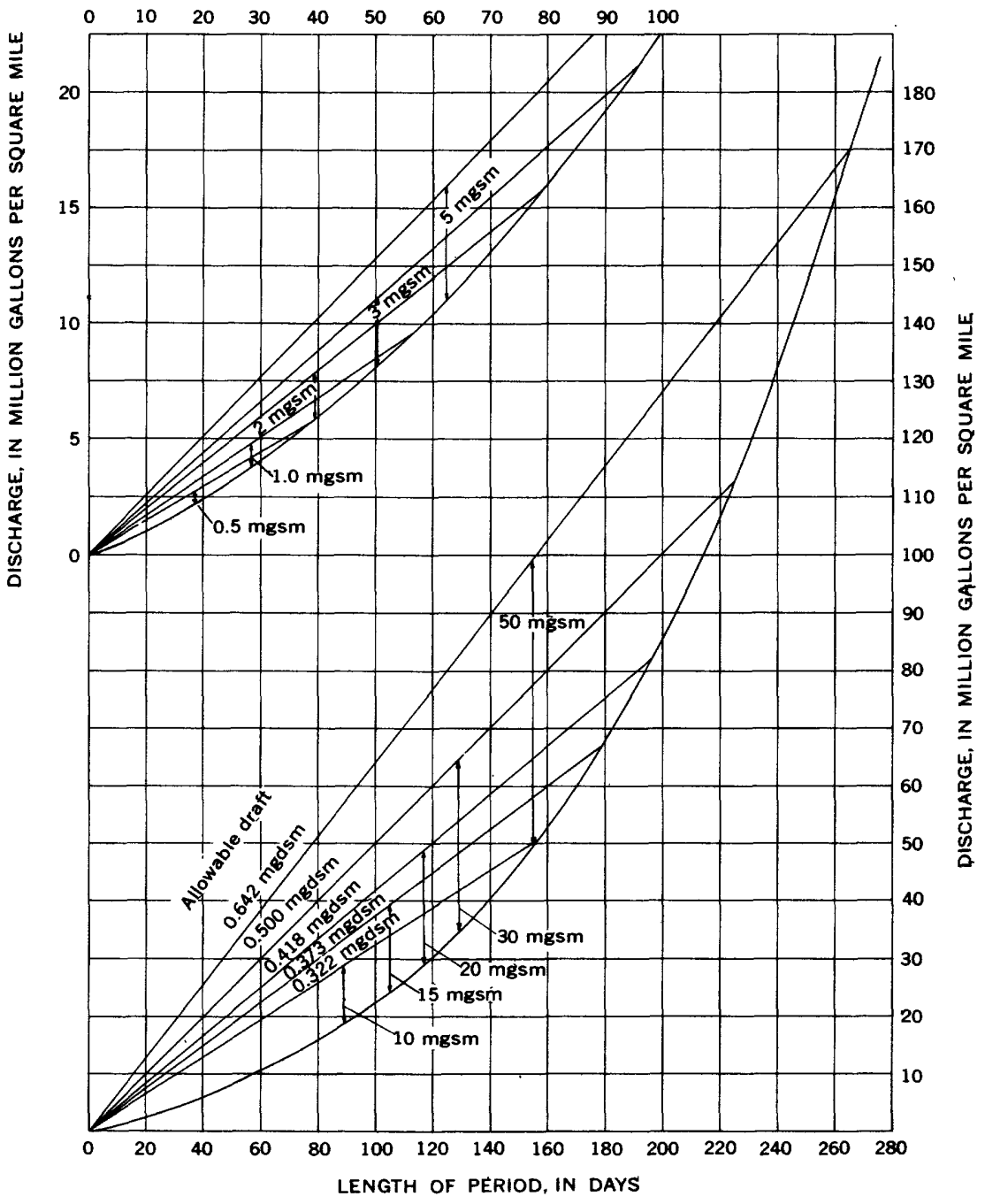

Figure 10.-Frequency-mass curve and draft-storage lines for a 10-year recurrence interyal, Beaver Kill at Cooks Falls, N.Y. Curve represents volume of discharge for indicated length of period. Draft rates are determined by the slope of the draft line, and corresponding storage is determined by the maximum vertical distance to the curve. For example, for a 10-year recurrence interval a storage capacity of 30 million gallons per square mile allows a draft of $0.50 \mathrm{mgd}$ per $\mathrm{sq} \mathrm{ml}$. 

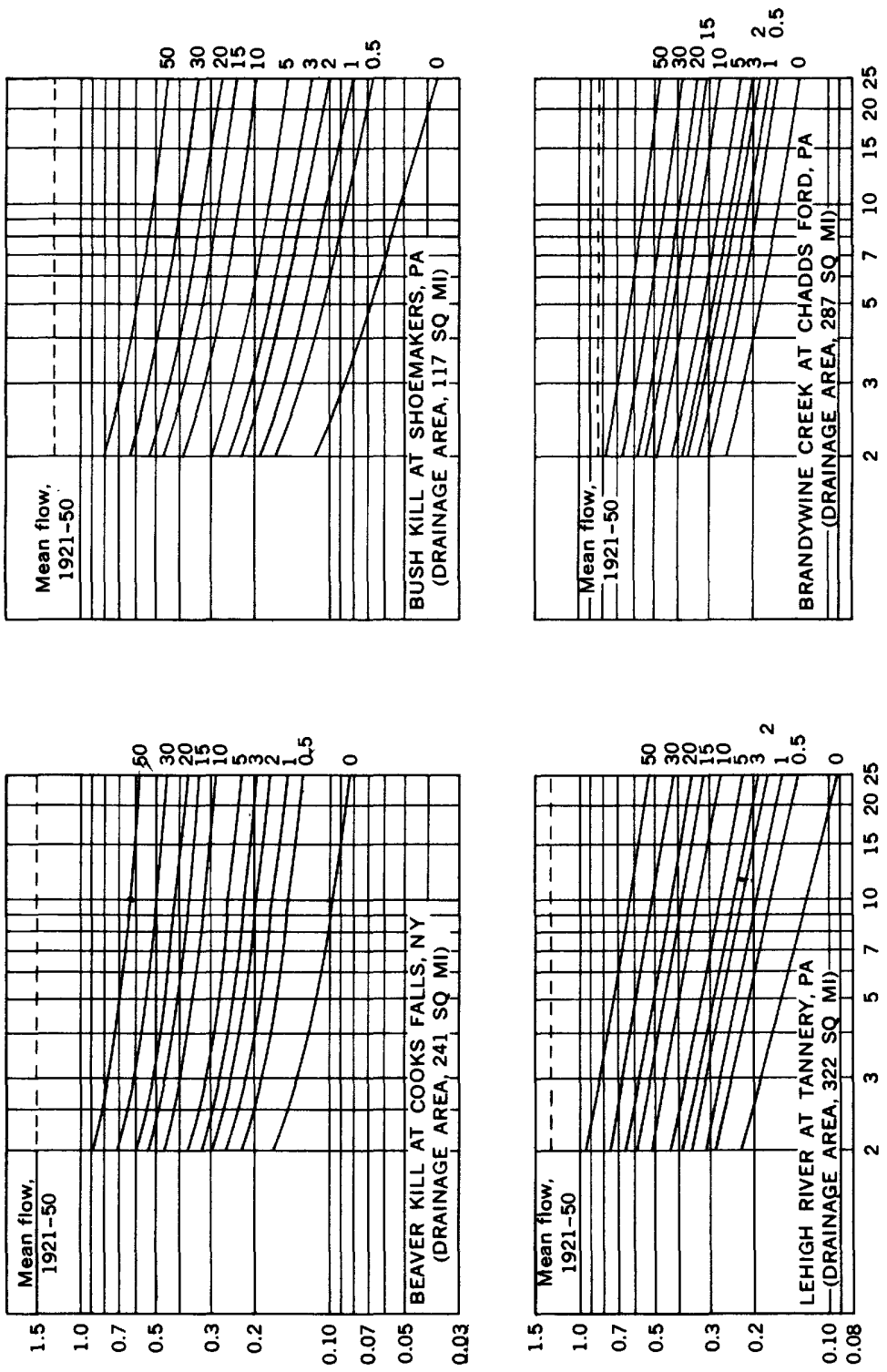

$\pm$

氖兽

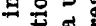

总

逢

运它

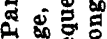

拣出

青罗运

홍훙

实定

里

현

岁通

宁苛。

o

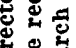

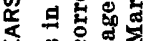

ш

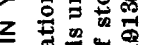

今茄司告

造

品

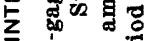

㟧

岕苟吉焉

品出出。

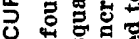

山

殅

要害

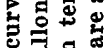

호용

몰

要管

要三

요

岁范泀

ఫ苟

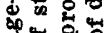

艛为

눙녕영

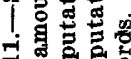

- 병영

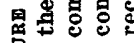

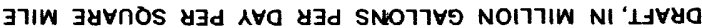

点 


\section{AREAL DRAFT-STORAGE RELATIONSHIPS}

The amount of storage required to provide selected rates of allowable draft can be estimated from the median annual 7-day low flow and the size of the drainage area by use of curves such as those shown. in figure 12. Each of the curves in the lower part of figure 12 is defined by the data for 19 stations, illustrated by the circles for a storage of 20 million gallons per square mile. The scatter of the circles, all but two of which are within 10 percent of the curve, is typical of the scatter of the points that define the other curves in the lower part of the figure. Values of median annual low flow used to define these curves were obtained from table 6 , and values of storage and allowable draft were obtained from table 7. The scatter of the points used to define these curves is due largely to true differences between stations, in which case the storage figures shown in table 7 are more reliable than values obtained from the curves.

The curves in the upper left-hand part of figure 12 are based on the curves in the lower left-hand part; either family of curves gives the same answer. Similar families of curves for a recurrence interval of 25 years are shown on the right side of figure 12 . The storage required shown by the curves in figure 12 is subject to the same bias and assumptions as the storage shown in figures 8 and 9 as well as to the inaccuracy shown by the scatter of the points on the left side of figure 12. The curves for zero storage are based on minimum 7-day flows at

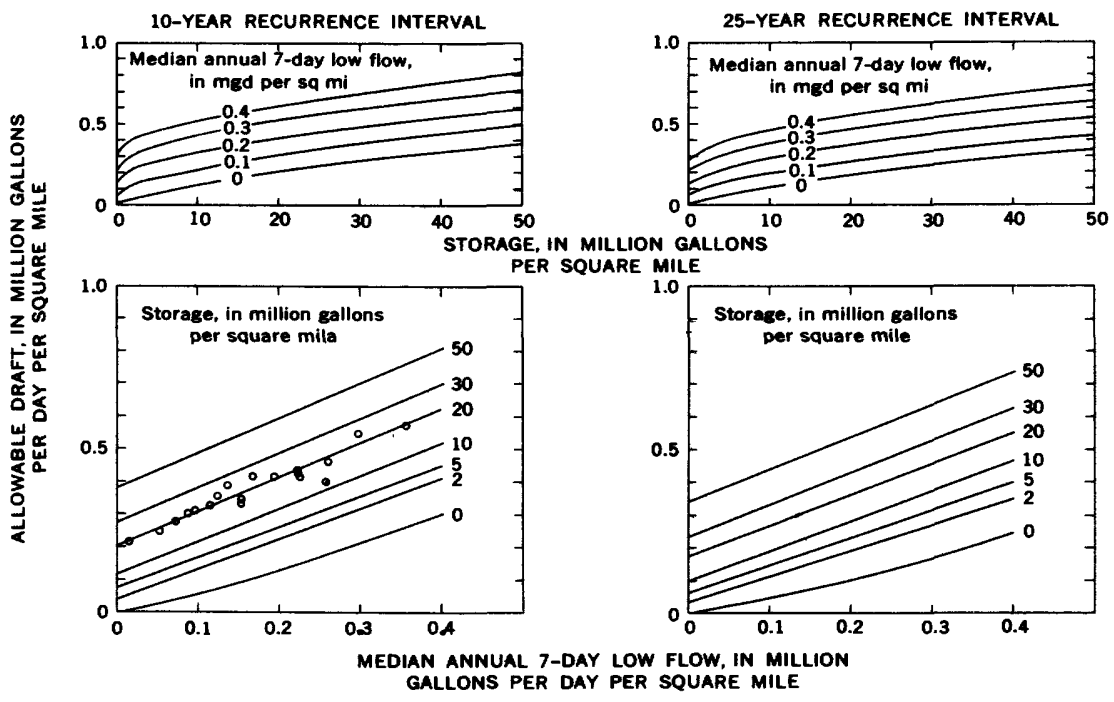

Frgoræ 12-Areal draft-storage relationships for 10- and 25-year recurrence intervals as a function of median annual low flow, Delaware River basin. Circles are computed values from table 7 for a storage of 20 million gallons per square mile. 
the 10- and 25-year recurrence intervals and thus neglect the small amount of storage that would be required to regulate the flow within the minimum 7 days. The curves in figure 12 should not be used for streams outside the Delaware River basin without verification of their applicability.

For most stream-gaging stations in the Delaware River basin, the amount of storage required can be estimated by using the median annual 7-day low flow shown in table 6 and in figure 13 as an index to enter the curves in figure 12. For example, the left side of figure 12 shows that a stream with a median annual low flow of $0.10 \mathrm{mgd}$ per sq $\mathrm{mi}$ would require storage of 50 million gallons per square mile at the 10-year recurrence interval to give an allowable draft of $0.5 \mathrm{mgd}$ per sq $\mathrm{mi}$, whereas a stream with a median annual low flow of $0.4 \mathrm{mgd}$ per sq $\mathrm{mi}$ would require less than $10 \mathrm{mgd}$ per sq $\mathrm{mi}$ to give the same draft rate per square mile. As the curves in figure 12 are not defined above $0.4 \mathrm{mgd}$ per sq $\mathrm{mi}$, the storage required for the three sites with the highest indices cannot be estimated in this way.

Estimating the amount of storage required for ungaged sites in the Delaware River basin requires that an estimate be made of the median annual low flow, but the variation in the values shown on figure 13 points out the danger of making such estimates without some observed basic data at the site. The median annual low flows for the 95 stations range from 0.02 to $0.65 \mathrm{mgd}$ per sq $\mathrm{mi}$ and vary widely between adjacent streams in all parts of the basin despite a general tendency to increase from north to south. A few discharge measurements made when the flow of a stream is not affected by rumoff from current rainfall would help identify the low-flow characteristics of the stream and thus go far toward improving the estimate of median annual low flow.

\section{REFERENCES}

Harker and others, 1964, Water resources of the Delaware River basin: U.S. Geol. Survey Prof. Paper 381 (in press).

Searcy, J. K., 1959, Flow-Duration curves: U.S. Geol. Survey Water-Supply Paper 1542-A, p. 1-33.

U.S. Army Corps of Engineers, 1960, Report on the comprehensive survey of the Delaware River basin, Philadelphia, Pa., U.S. Army Engr. District.

U.S. Geological Survey, 1960, Compilation of records of surface waters of the United States through September 1950, Pt. 1-B, North Atlantic Slope basins, New York to York River: U.S. Geol. Survey Water-Supply Paper $1302,679 \mathrm{p}$. 


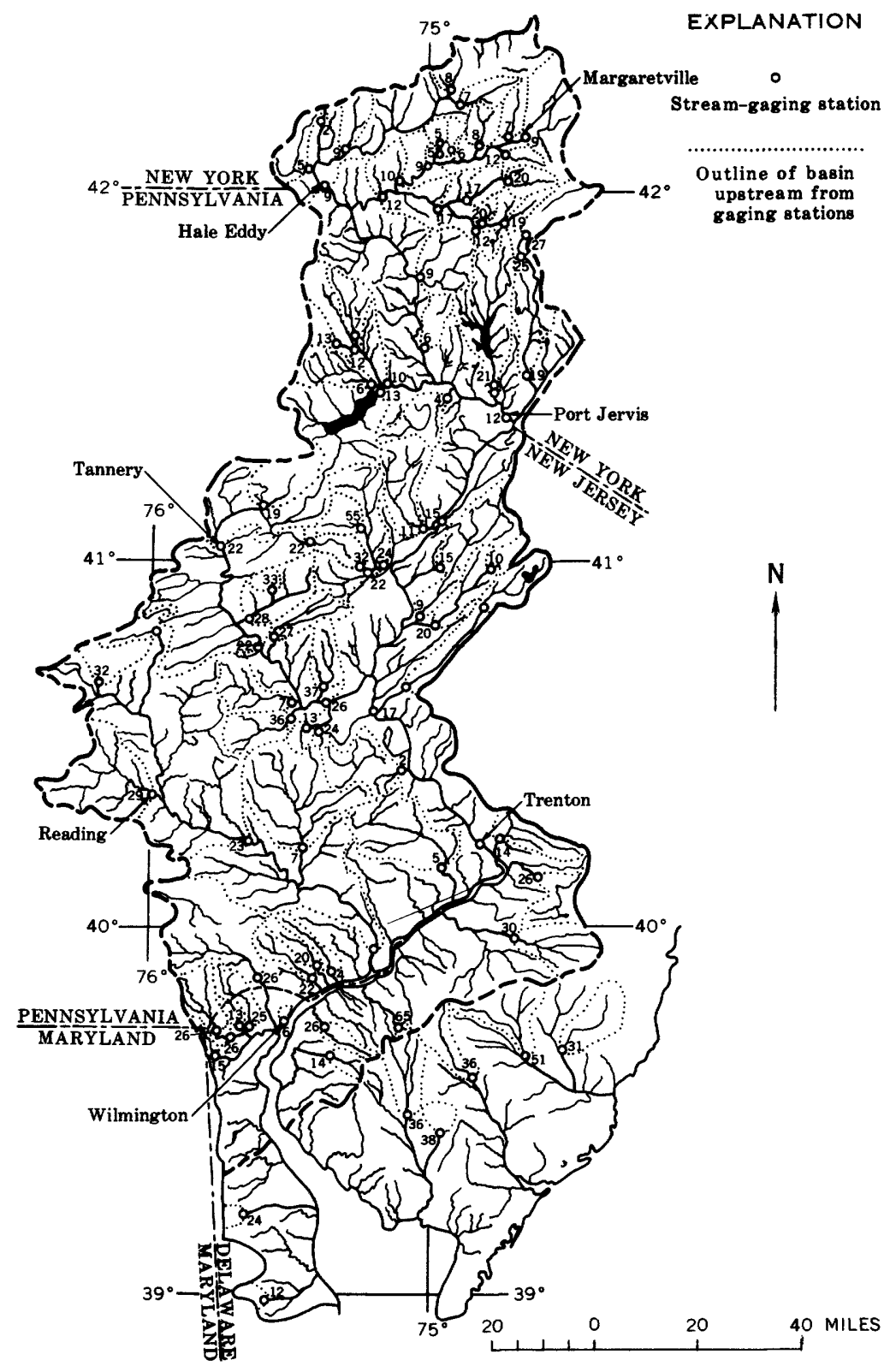

Figune 13.-Map of median annual low flow for Delaware River basin showing minimum 7-day discharge, in hundredths of a million gallons per day per square mile, at the 2-year recurrence interval for unregulated stream-gaging stations. 
STREAMS, DELAWARE RIVER BASIN, SOUTHERN NEW JERSEY N29

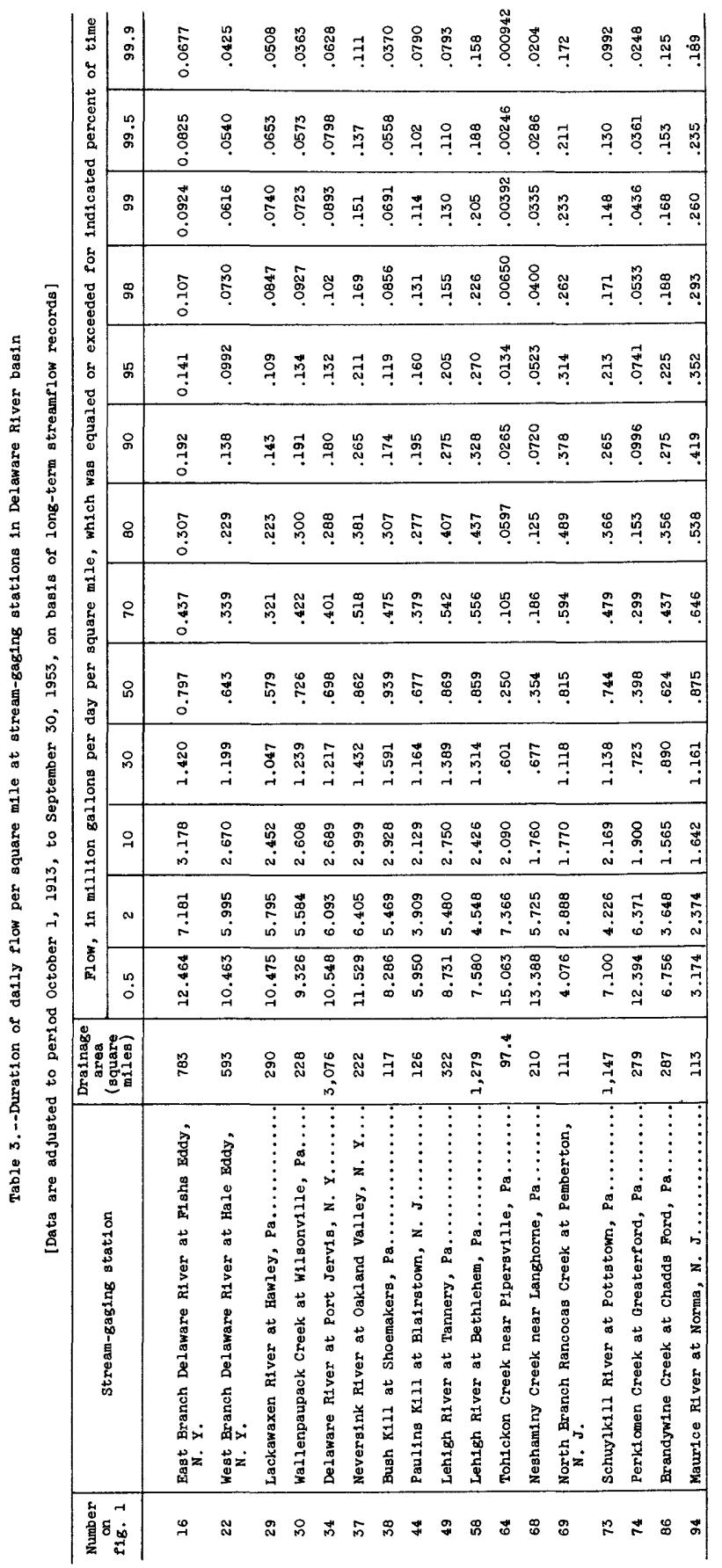




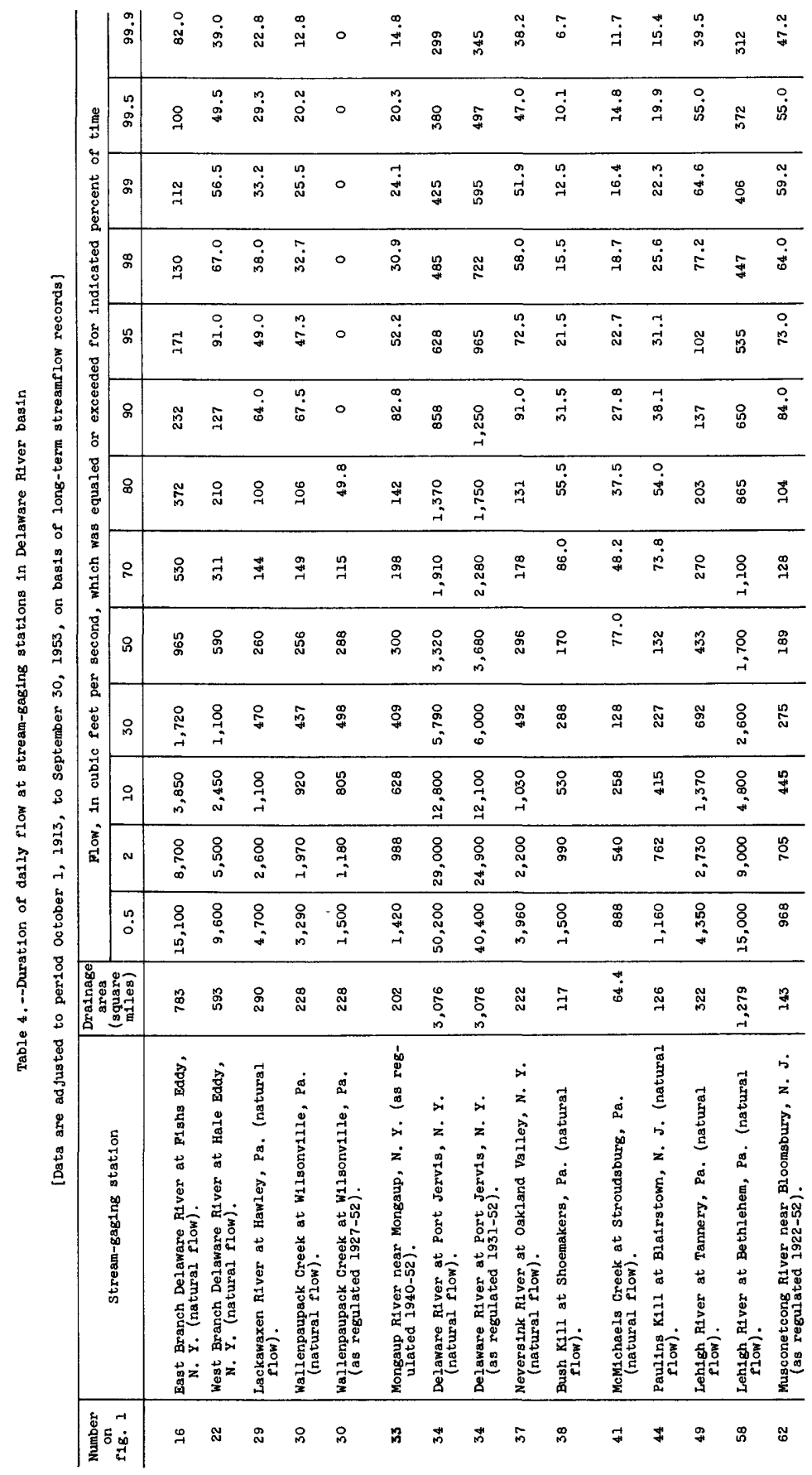




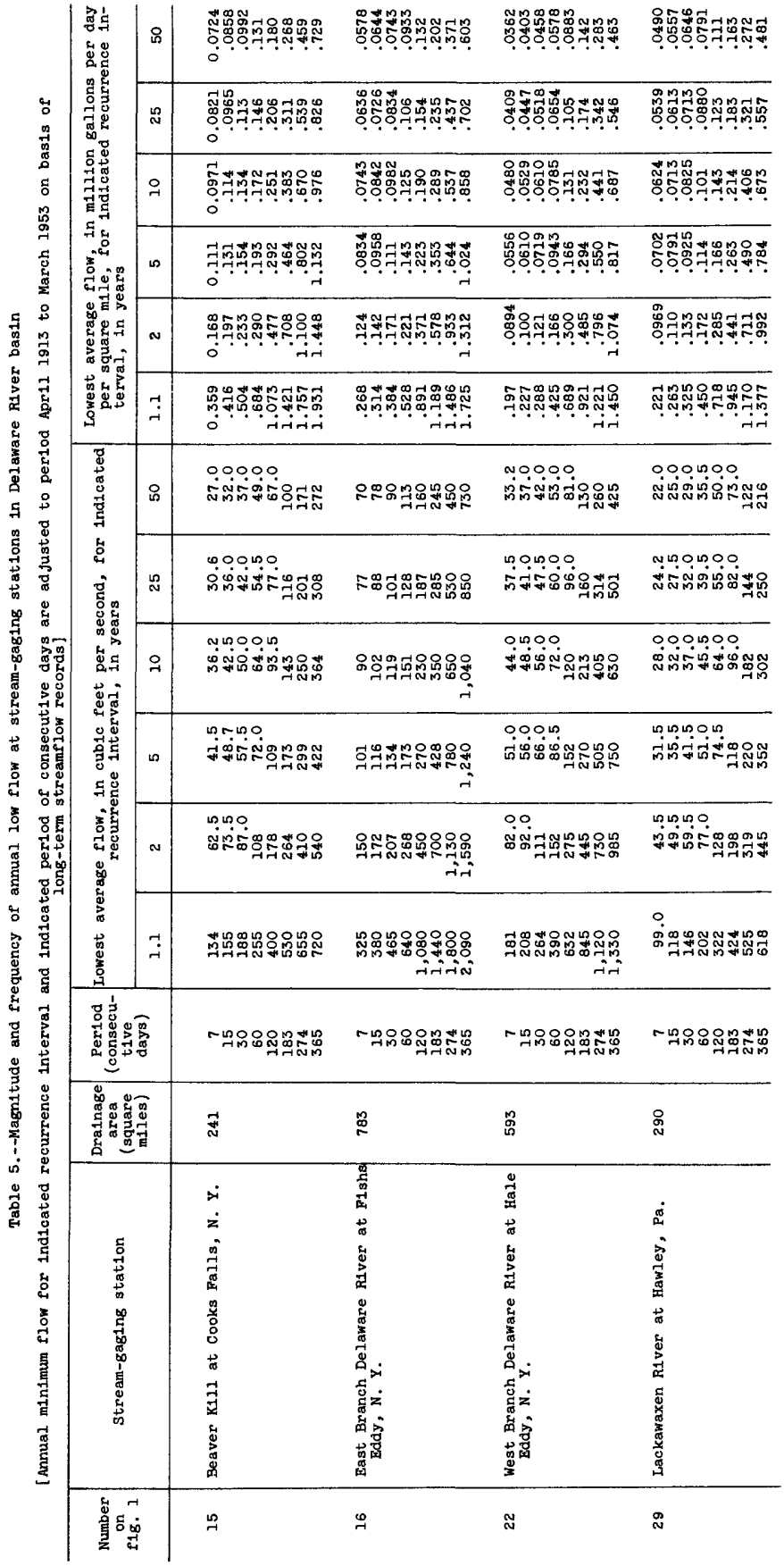




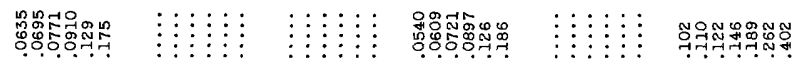

\begin{tabular}{|c|c|c|c|c|c|}
\hline 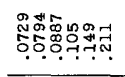 & 交 & $\begin{array}{l}\vdots \vdots \vdots \\
\vdots \vdots \\
\vdots\end{array}$ & 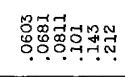 & & 邹 \\
\hline ריד & : : : : : & & 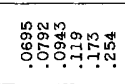 & & \\
\hline 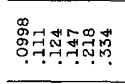 & & & 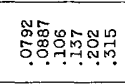 & & 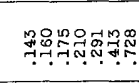 \\
\hline 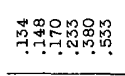 & $\vdots$ & & 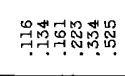 & & $8 n^{2}-13 x$ \\
\hline 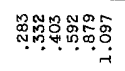 & $\vdots \vdots \vdots \vdots \vdots \vdots \vdots \vdots$ & & 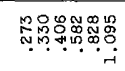 & & 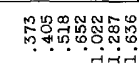 \\
\hline कर कำ & Do & 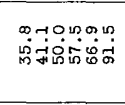 & 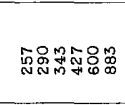 & 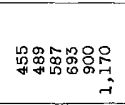 & \\
\hline 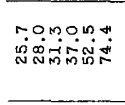 & o & 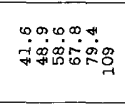 & 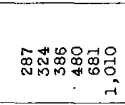 & 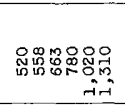 & 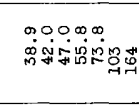 \\
\hline 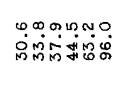 & 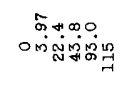 & 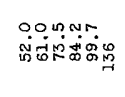 & 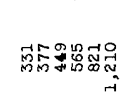 & 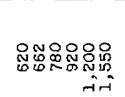 & 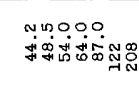 \\
\hline 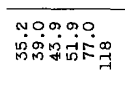 & 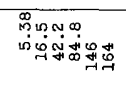 & 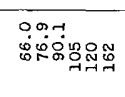 & 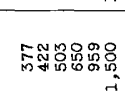 & 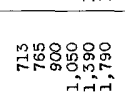 & 9ำ \\
\hline & 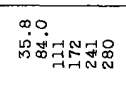 & 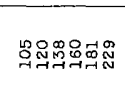 & 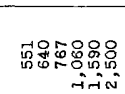 & ระ:워ำ & : \\
\hline
\end{tabular}

\begin{tabular}{|c|c|c|c|c|c|}
\hline & 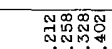 & & & & \\
\hline 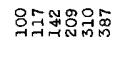 & $\overbrace{-\oplus}^{\infty} \cdots$ & 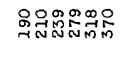 & 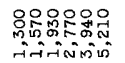 & 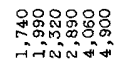 & 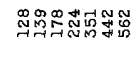 \\
\hline
\end{tabular}

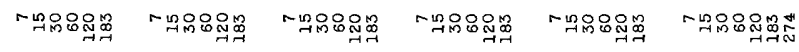

\begin{tabular}{|c|c|c|c|c|c|}
\hline$\stackrel{\mathbb{N}}{\text { N }}$ & $\stackrel{\infty}{N}$ & ָั & $\begin{array}{l}0 \\
5 \\
0 \\
\text { is }\end{array}$ & 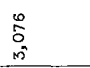 & 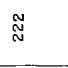 \\
\hline 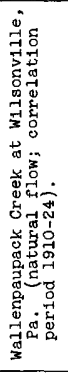 & 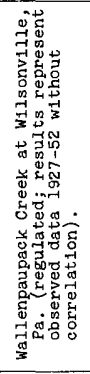 & 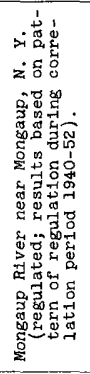 & 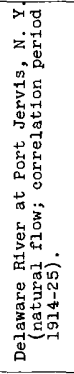 & 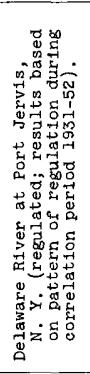 & 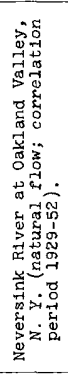 \\
\hline 욤 & 욤 & 盟 & 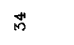 & $\ddot{~}$ & in \\
\hline
\end{tabular}


N34 CONTRIBUTIONS TO THE HYDROLOGY OF THE UNITED STATES

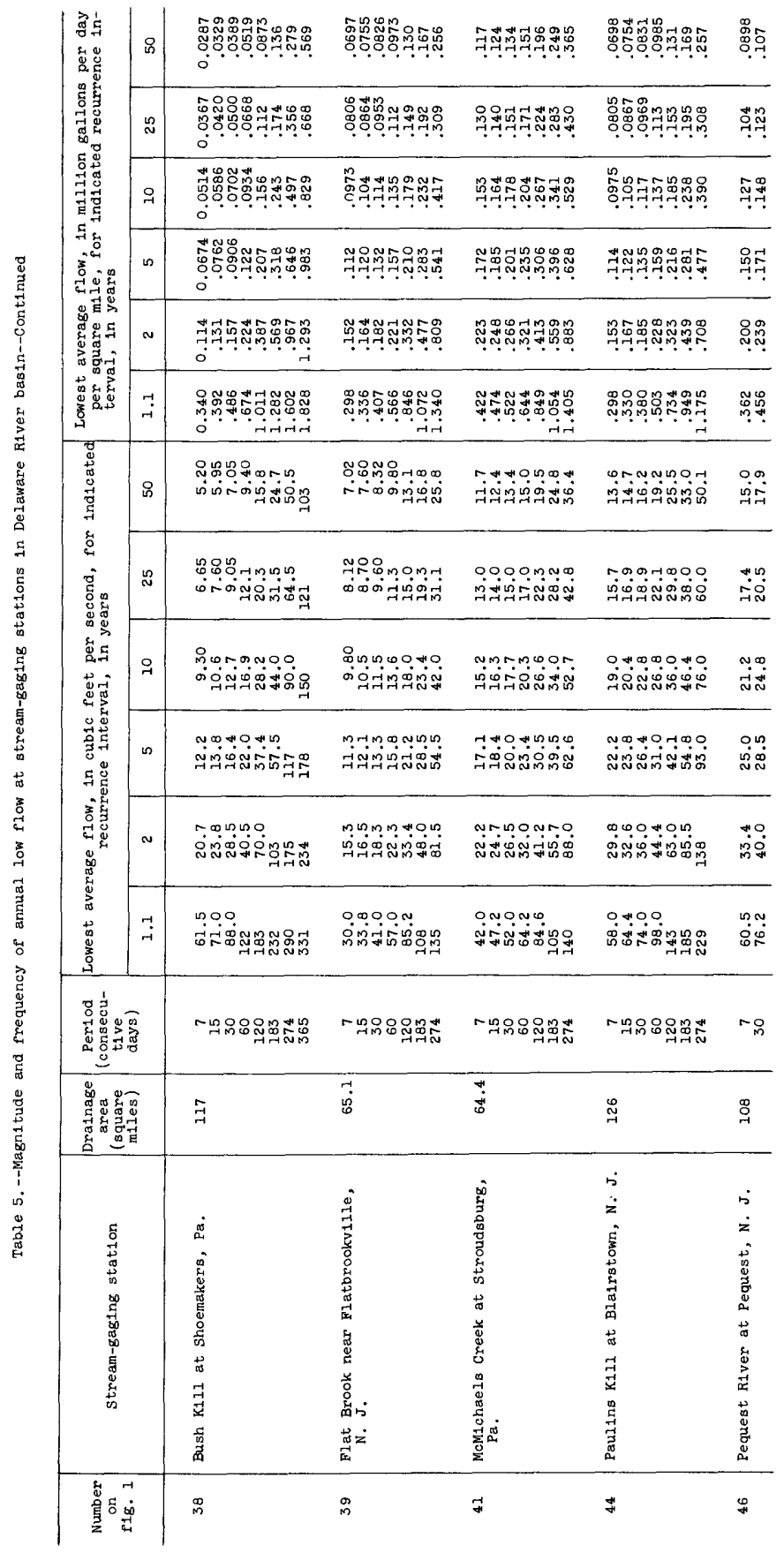


STREAMS, DELAWARE RIVER BASIN, SOUTHERN NEW JERSEY N35

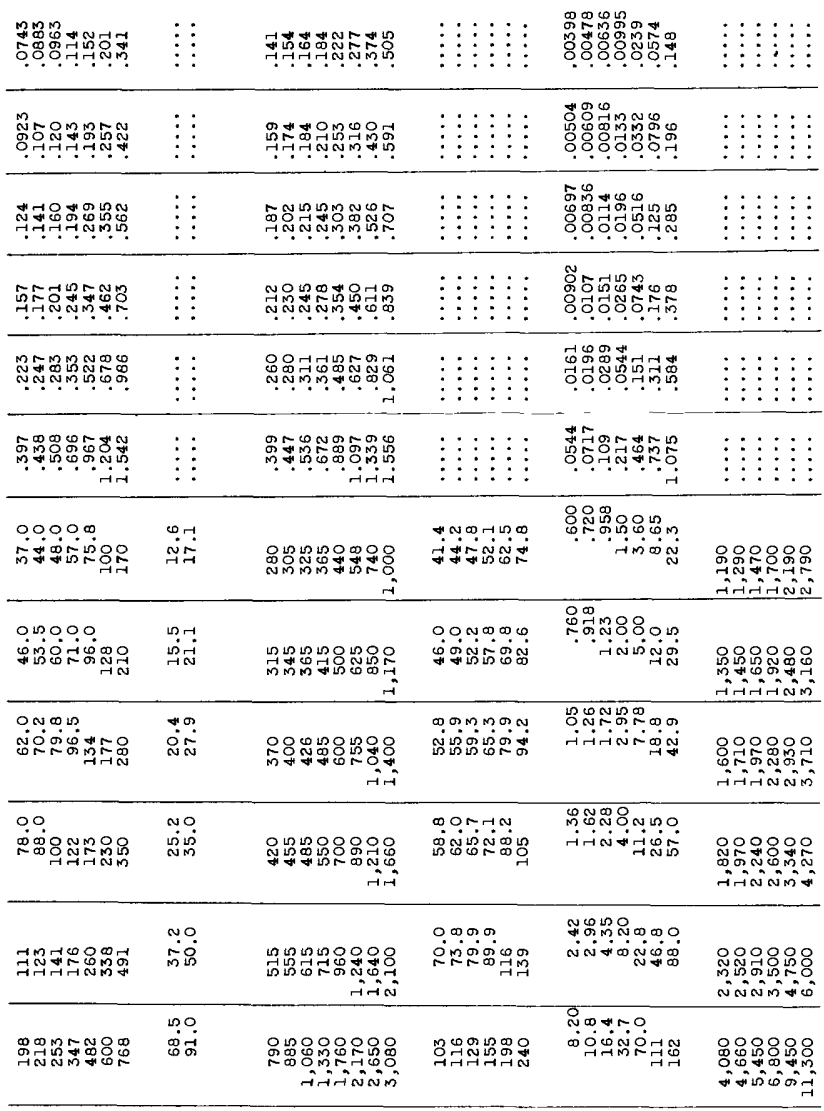

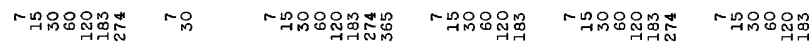

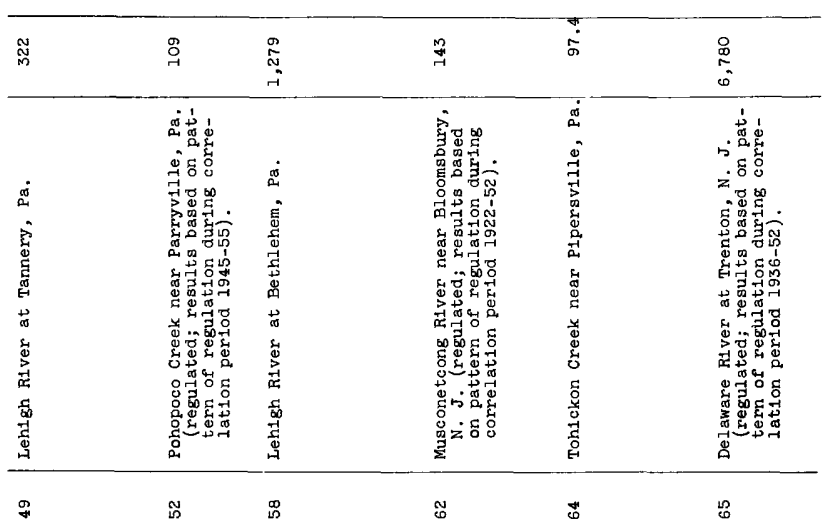




\begin{tabular}{|c|c|c|c|c|}
\hline \multirow{6}{*}{ 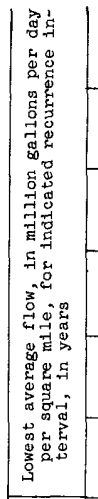 } & 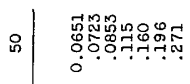 & 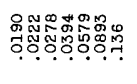 & 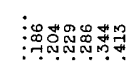 & 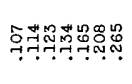 \\
\hline & 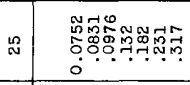 & 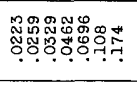 & 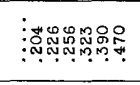 & 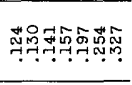 \\
\hline & 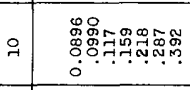 & 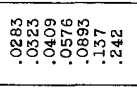 & 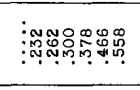 & 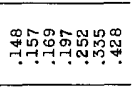 \\
\hline & 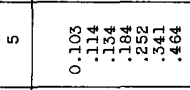 & 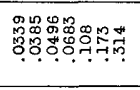 & 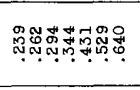 & 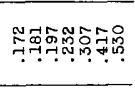 \\
\hline & 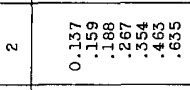 & 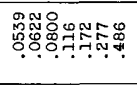 & 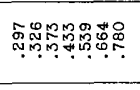 & 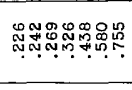 \\
\hline & 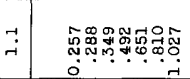 & 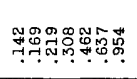 & 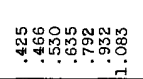 & 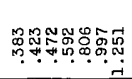 \\
\hline 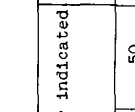 & 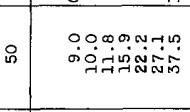 & 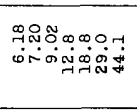 & 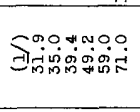 & 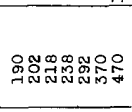 \\
\hline 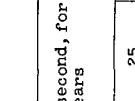 & 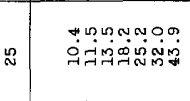 & 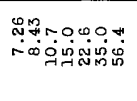 & 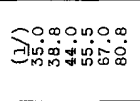 & 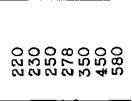 \\
\hline 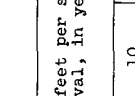 & 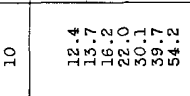 & 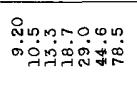 & 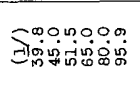 & 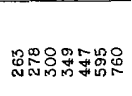 \\
\hline 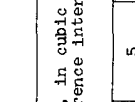 & 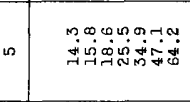 & 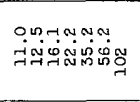 & 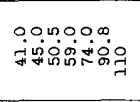 & 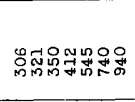 \\
\hline 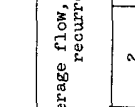 & 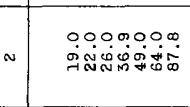 & 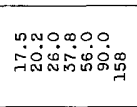 & 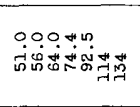 & 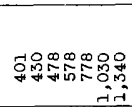 \\
\hline 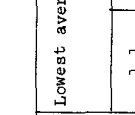 & 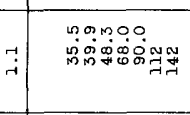 & 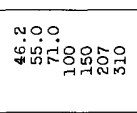 & 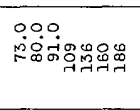 & 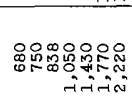 \\
\hline 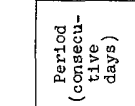 & 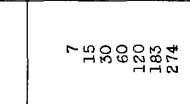 & 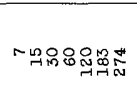 & r & 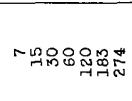 \\
\hline 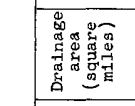 & 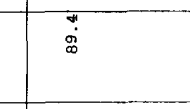 & 옥 & $\overrightarrow{7}$ & $\stackrel{5}{\stackrel{5}{4}}$ \\
\hline 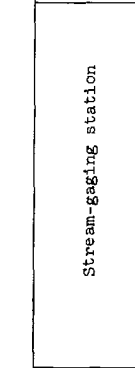 & 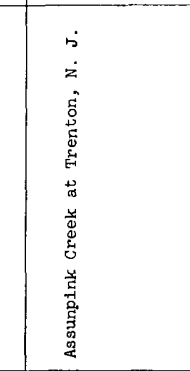 & 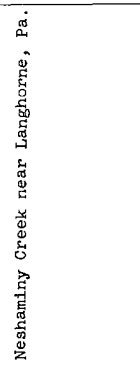 & 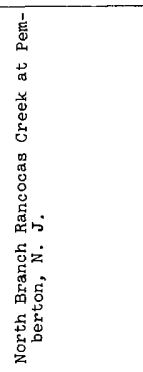 & 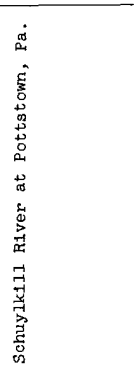 \\
\hline 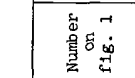 & 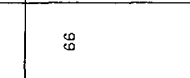 & $\infty$ & 品 & $\stackrel{R}{\sim}$ \\
\hline
\end{tabular}


STREAMS, DELAWARE RIVER BASIN, SOUTHERN NEW JERSEY N37

\begin{tabular}{|c|c|c|c|c|}
\hline 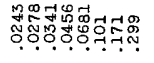 & & 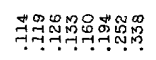 & 药 & 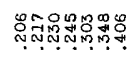 \\
\hline 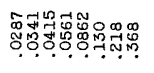 & & 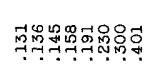 & 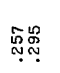 & 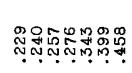 \\
\hline 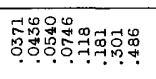 & 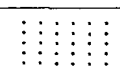 & 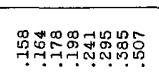 & 然 & 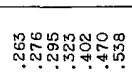 \\
\hline 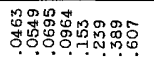 & $\begin{array}{l}\vdots \vdots \vdots \\
\vdots \vdots \\
\vdots\end{array}$ & 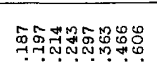 & 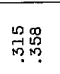 & 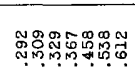 \\
\hline 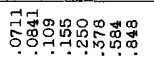 & & 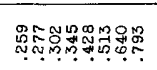 & 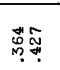 & 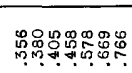 \\
\hline 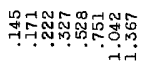 & & 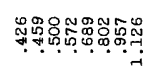 & 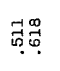 & 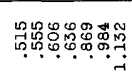 \\
\hline 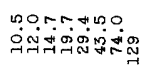 & 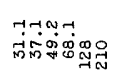 & 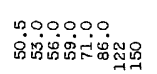 & 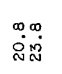 & 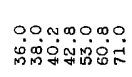 \\
\hline 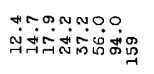 & 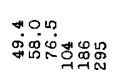 & 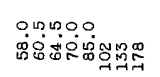 & 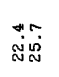 & 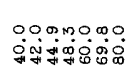 \\
\hline 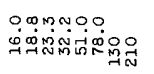 & 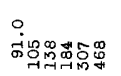 & 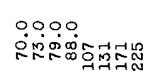 & 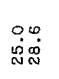 & 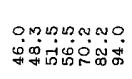 \\
\hline 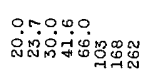 & 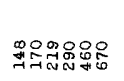 & 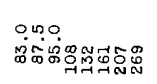 & 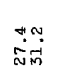 & 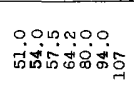 \\
\hline 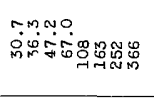 & 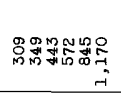 & 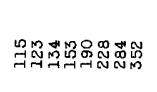 & 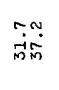 & 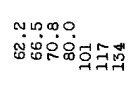 \\
\hline 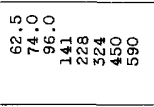 & 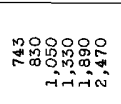 & 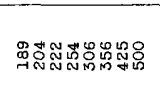 & 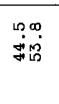 & 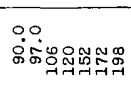 \\
\hline 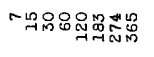 & 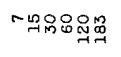 & 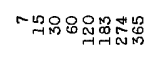 & ro & r \\
\hline$\stackrel{\mathscr{N}}{\text { N }}$ & 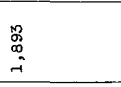 & $\underset{\sim}{\tilde{D}}$ & $\begin{array}{l}n \\
0 \\
0 \\
0\end{array}$ & $\stackrel{m}{\rightarrow}$ \\
\hline 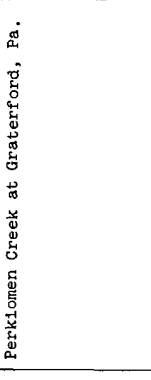 & 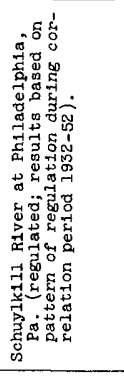 & 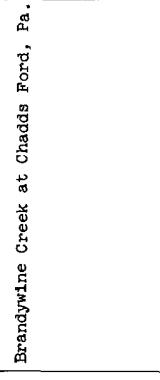 & 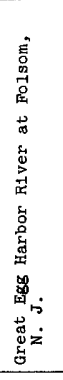 & 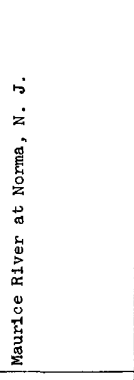 \\
\hline t" & $\stackrel{2}{\sim}$ & $\stackrel{\infty}{\infty}$ & 另 & \$ \\
\hline
\end{tabular}




\begin{tabular}{|c|c|c|c|c|c|c|c|c|c|c|c|c|}
\hline $\begin{array}{l}0 \\
\frac{n}{7} \\
0 \\
0 \\
0 \\
0\end{array}$ & 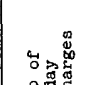 & 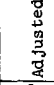 & & $\underset{0}{\tilde{H}}$ & 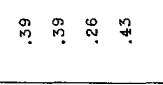 & โุ \& \& & & 品 & 品 & 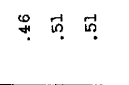 & 品 & $\stackrel{1}{!}$ \\
\hline 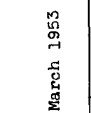 & 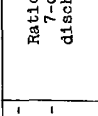 & 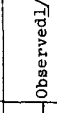 & & $\begin{array}{l}\overrightarrow{0} \\
\stackrel{0}{0} \\
0\end{array}$ & 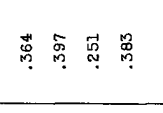 & 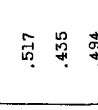 & & 孪 & 品 & 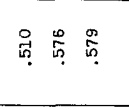 & 莒 & 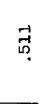 \\
\hline $\begin{array}{l}\Sigma \\
\vdots \\
\vdots \\
9 \\
9 \\
9\end{array}$ & 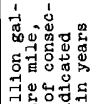 & 票 & $\begin{array}{l}5 \\
\vdots \\
\&\end{array}$ & $\begin{array}{l}5 \\
\vdots \\
0 \\
0 \\
0\end{array}$ & 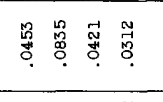 & 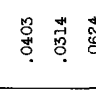 & & 足 & $\stackrel{\sharp}{=}$ & Э & Eิ & $\stackrel{\infty}{7}$ \\
\hline $\begin{array}{l}\overrightarrow{7} \\
\overrightarrow{4} \\
5\end{array}$ & 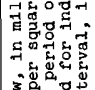 & 方 & $\begin{array}{l}5 \\
5 \\
N\end{array}$ & 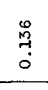 & Э & 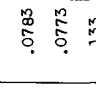 & & $\stackrel{2}{7}$ & 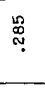 & 莡 & $\stackrel{\substack{\infty \\
\hdashline}}{?}$ & ֻู \\
\hline 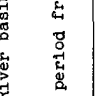 & 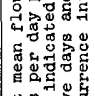 & 兽 & 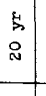 & $\begin{array}{l}\stackrel{9}{\sharp} \\
\stackrel{0}{0} \\
\dot{0}\end{array}$ & 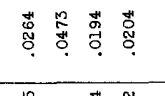 & 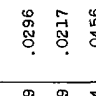 & & 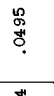 & $\stackrel{n}{\dddot{?}}$ & 营。ํำ & ثิ & $\begin{array}{l}\text { 足 } \\
\stackrel{0}{0} \\
\stackrel{0}{0}\end{array}$ \\
\hline 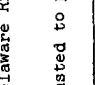 & \begin{tabular}{|l|l} 
\\
0
\end{tabular} & $\stackrel{1}{2}$ & $\begin{array}{l}5 \\
5 \\
5 \\
\end{array}$ & $\begin{array}{l}\text { ב̃ } \\
0 \\
0 \\
0 \\
\end{array}$ & 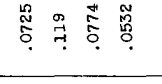 & 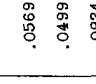 & 芯 & 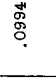 & 芯 & ఝิ ન્ન & $\stackrel{\infty}{7}$ & $\stackrel{\infty}{\infty}$ \\
\hline \begin{tabular}{l|}
5 \\
0 \\
$\Phi$ \\
0 \\
0 \\
0 \\
0 \\
0 \\
0 \\
0
\end{tabular} & 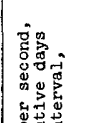 & 苚 & $\begin{array}{l}5 \\
5 \\
0 \\
N\end{array}$ & 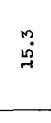 & 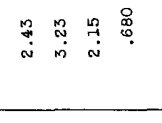 & 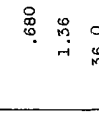 & : & $\begin{array}{l}n \\
0 \\
d\end{array}$ & $\begin{array}{l}\hat{o} \\
\dot{\sigma}\end{array}$ & 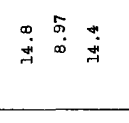 & $\underset{\substack{\infty \\
i \\
\sim}}{\sim}$ & $\stackrel{q}{\dot{q}}$ \\
\hline 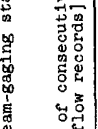 & 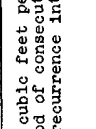 & is & $\begin{array}{l}5 \\
2 \\
\sim\end{array}$ & 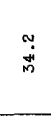 & 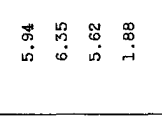 & 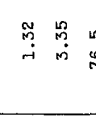 & 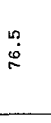 & 官 & $\stackrel{\circ}{\stackrel{\infty}{\oplus}}$ & 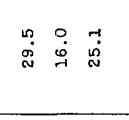 & $\stackrel{\circ}{?}$ & $\stackrel{\circ}{\dot{\infty}}$ \\
\hline 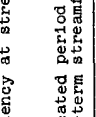 & 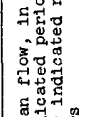 & 超 & $\begin{array}{l}4 \\
5 \\
0 \\
0\end{array}$ & $\begin{array}{l}\circ \\
\stackrel{9}{-}\end{array}$ & 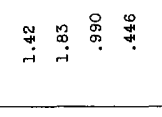 & 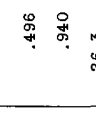 & 虫 & o & $\underset{0}{\stackrel{0}{0}}$ & 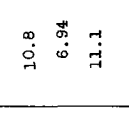 & $\stackrel{\substack{0 \\
i}}{i}$ & $\stackrel{\circ}{\sim}$ \\
\hline 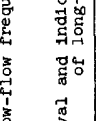 & 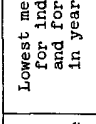 & & $\begin{array}{c}5 \\
5 \\
w\end{array}$ & $\stackrel{\circ}{\mathfrak{a}}$ & 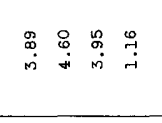 & 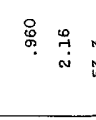 & 登 & $\underset{\infty}{\vec{\infty}}$ & $\stackrel{9}{\stackrel{\sim}{\sim}}$ & 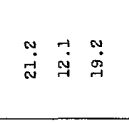 & $\begin{array}{l}\tilde{\Xi} \\
\dot{m}\end{array}$ & ֻُ \\
\hline 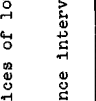 & 品 & & & 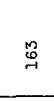 & 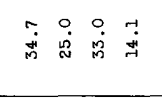 & $\begin{array}{ll}0 & 0 \\
\dot{0} & \stackrel{\dot{\Phi}}{\infty}\end{array}$ & $\frac{p}{n}$ & $\$$ & $\begin{array}{l}\infty \\
\dot{0} \\
\dot{q}\end{array}$ & 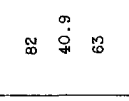 & $\stackrel{\infty}{\dot{\Phi}}$ & N \\
\hline 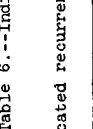 & $\begin{array}{l}\text { and } \\
\text { d. } \\
0 \\
0 \\
0\end{array}$ & 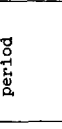 & & 芯 & 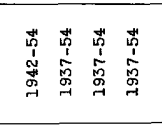 & 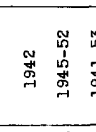 & $\begin{array}{l}\text { 虽 } \\
\text { 声 } \\
\text { 品 }\end{array}$ & 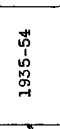 & 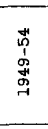 & 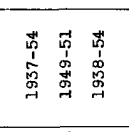 & 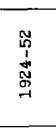 & 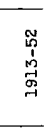 \\
\hline 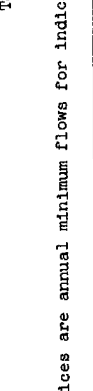 & 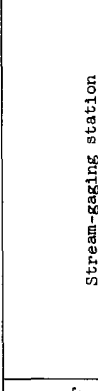 & & & 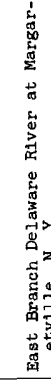 & 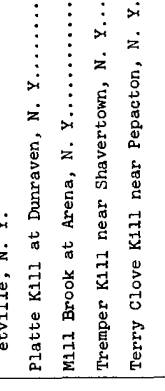 & 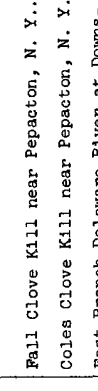 & & 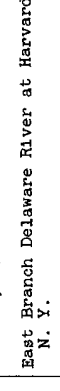 & 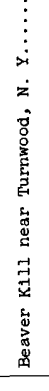 & 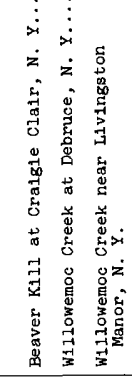 & 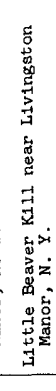 & 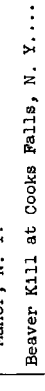 \\
\hline & & & & 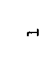 & N in th th & 0 & $\infty$ & $\infty$ & or & $\exists \cong$ & $\exists$ & $\stackrel{\leftrightarrow}{\sim}$ \\
\hline
\end{tabular}


STREAMS, DELAWARE RIVER BASIN, SOUTHERN NEW JERSEY N39

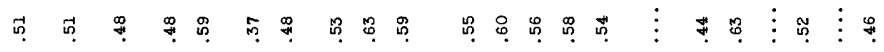

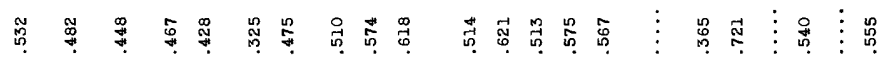

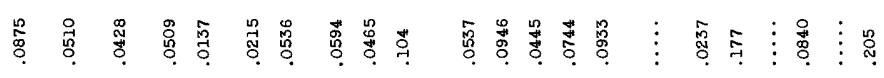

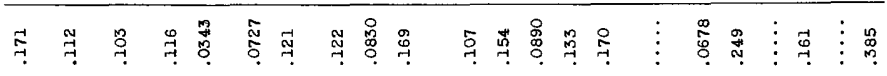

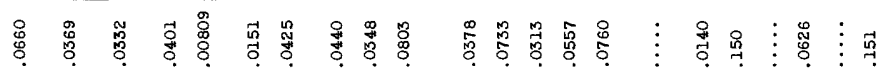

苞劳

品

亏 莣

家

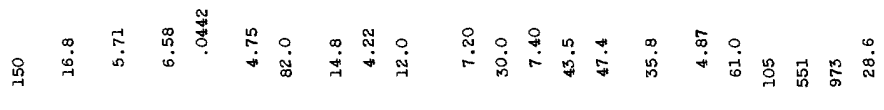

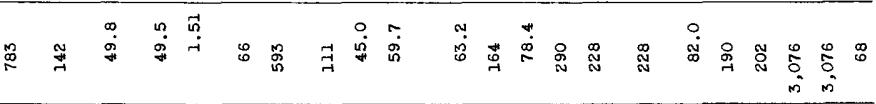

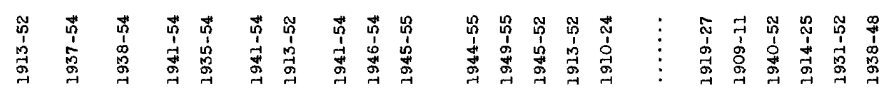

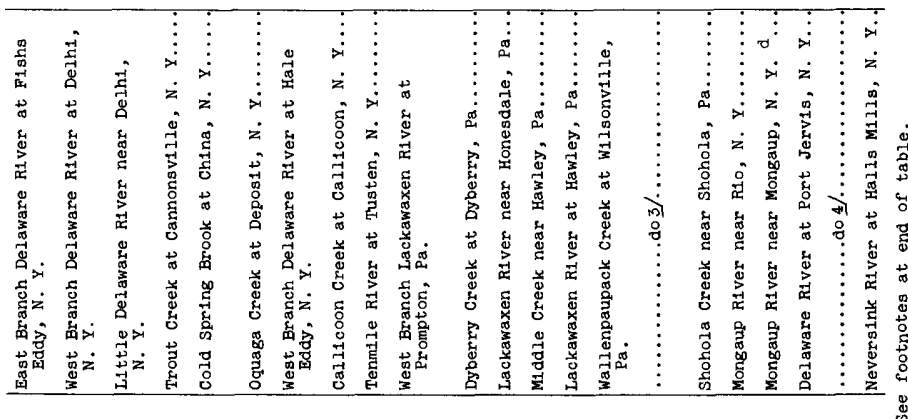

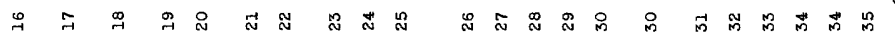




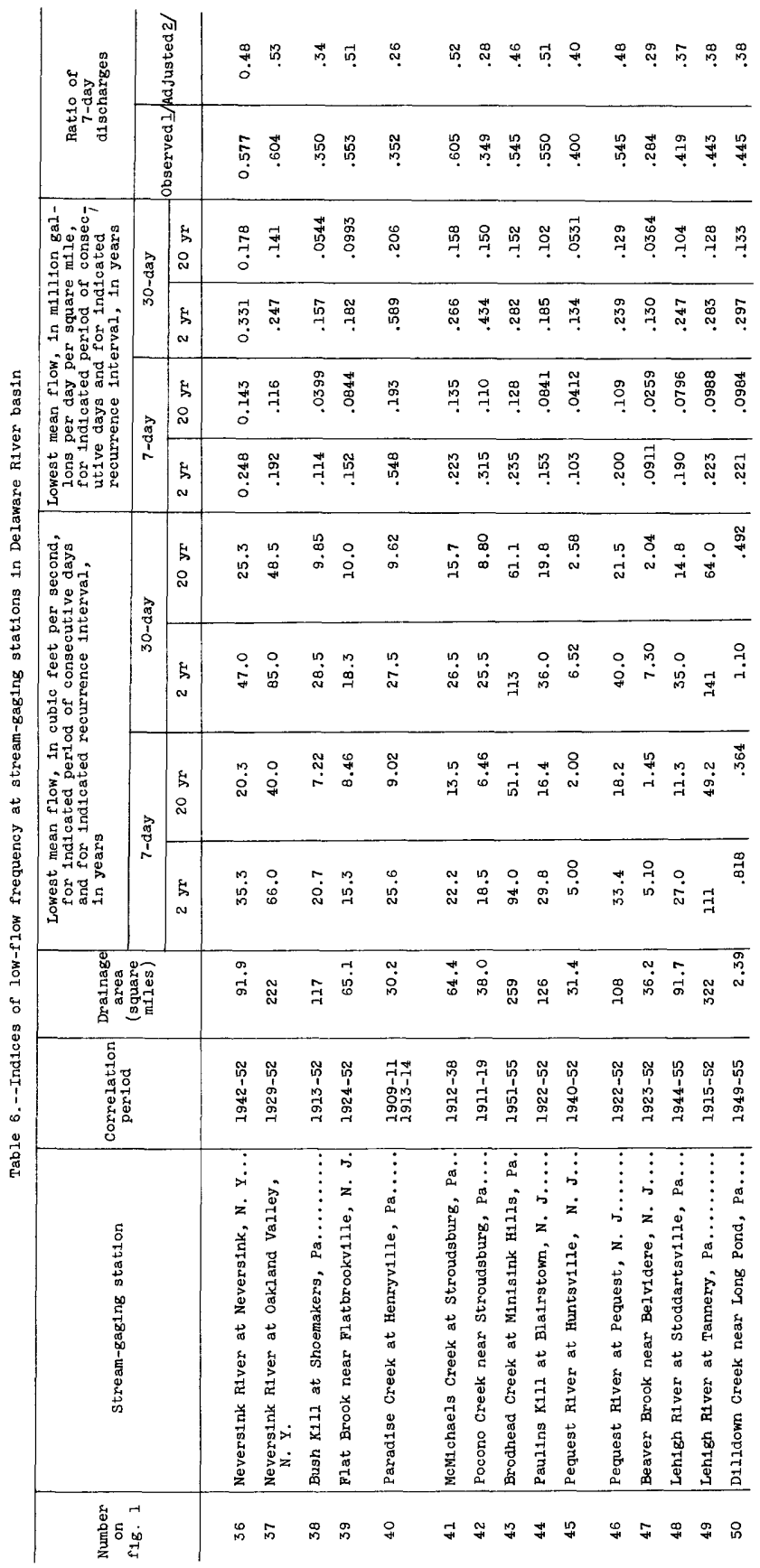




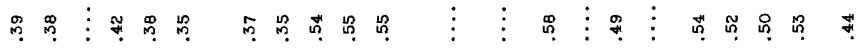

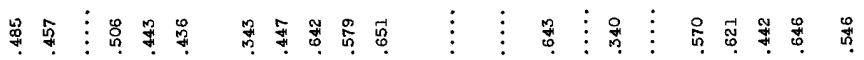

苞

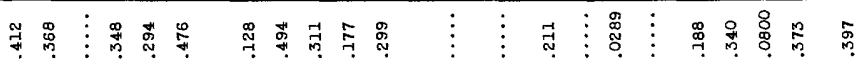

ๆ

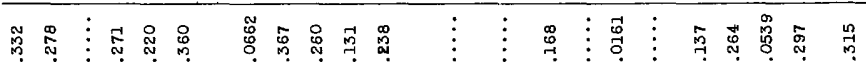

离

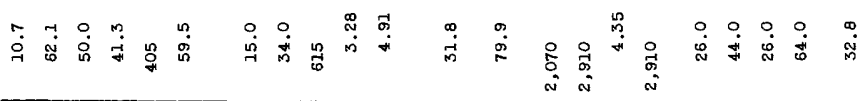

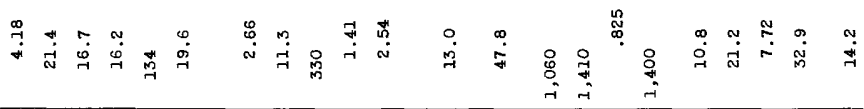

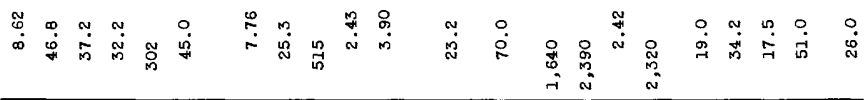

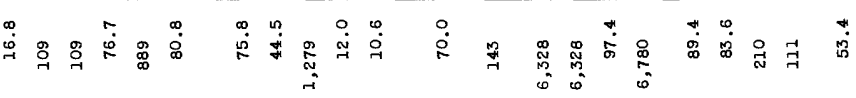

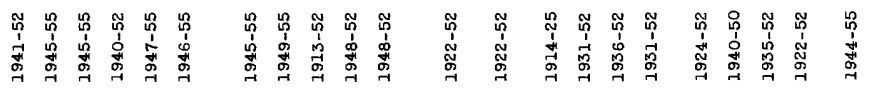

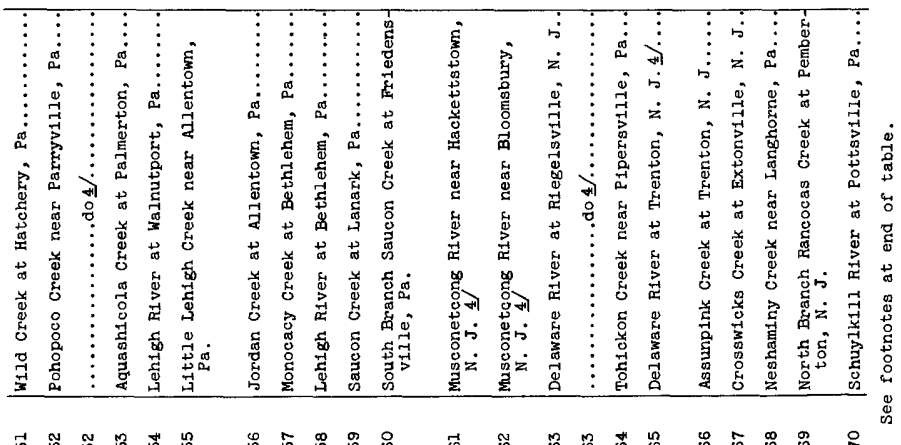

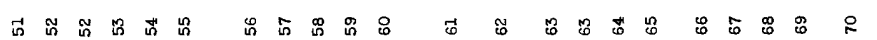




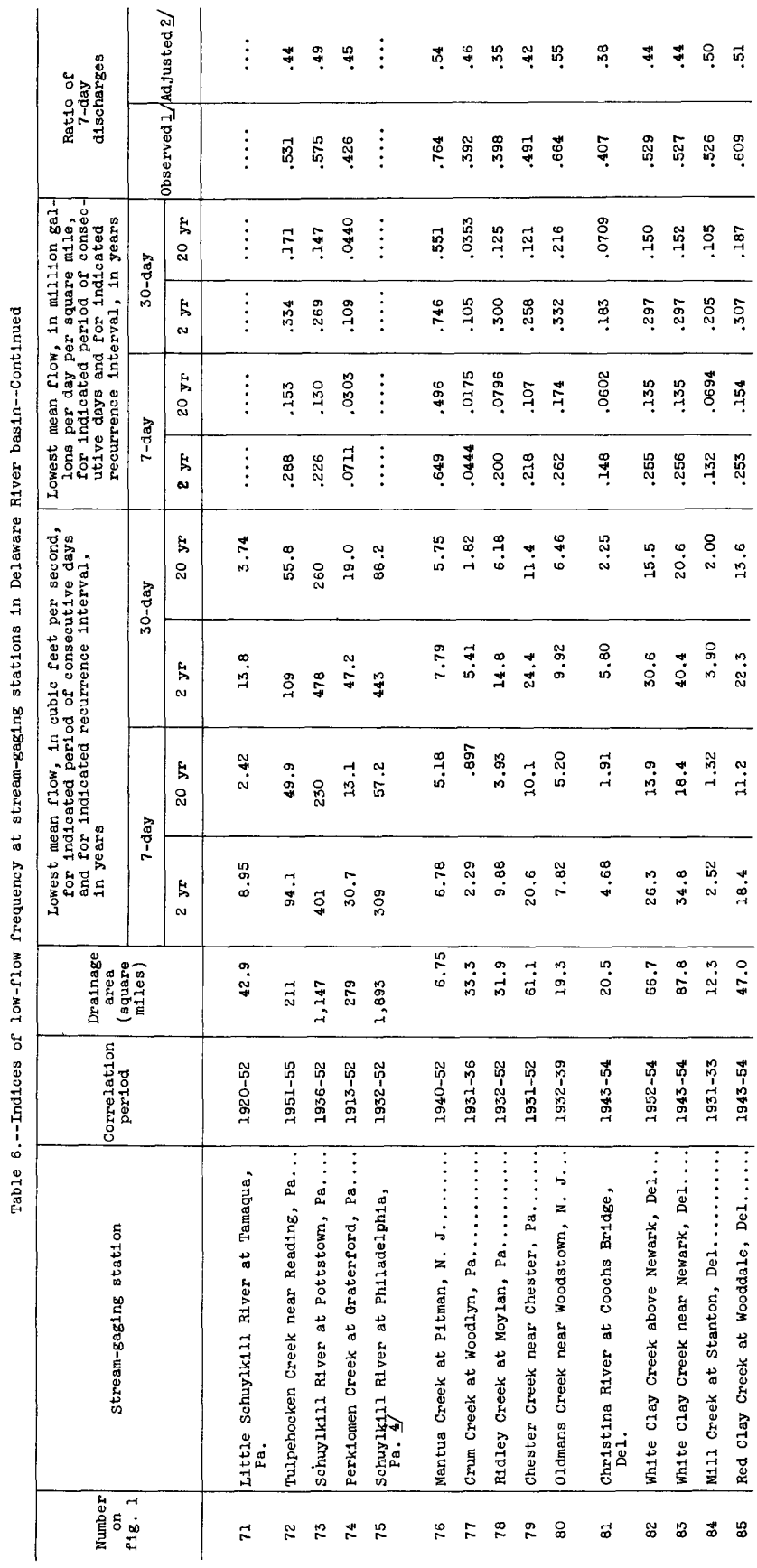


STREAMS, DELAWARE RIVER BASIN, SOUTHERN NEW JERSEY N43

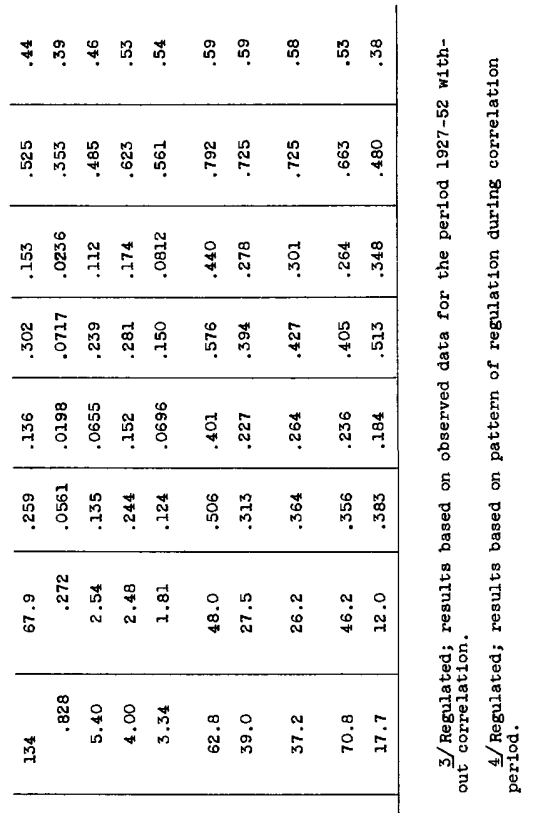

尊

号

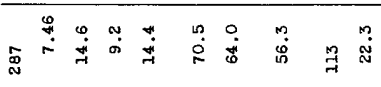

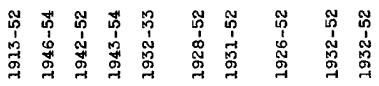

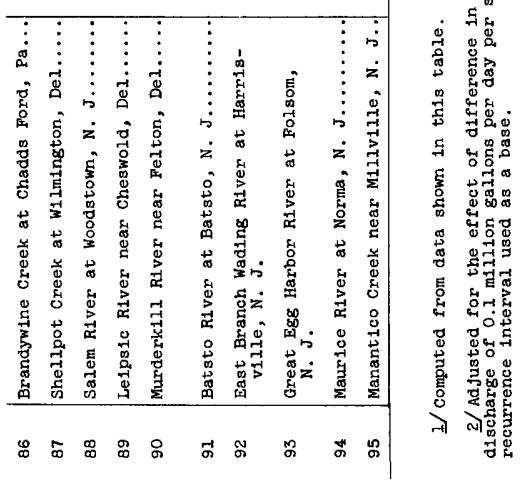


N44 CONTRIBUTIONS TO THE HYDROLOGY OF THE UNITED STATES

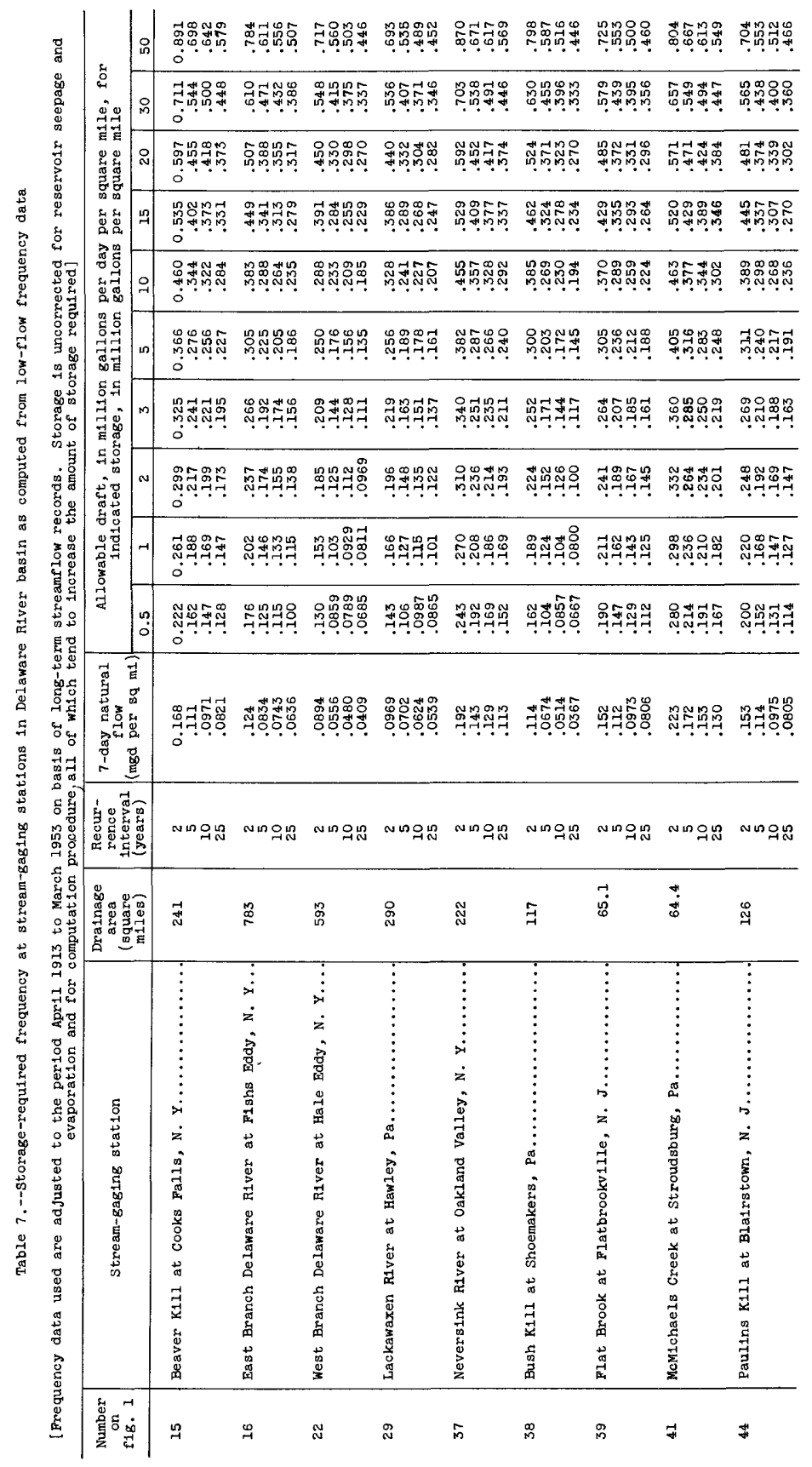


STREAMS, DELAWARE RIVER BASIN, SOUTHERN NEW JERSEY N45

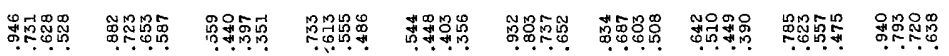

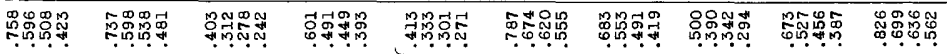

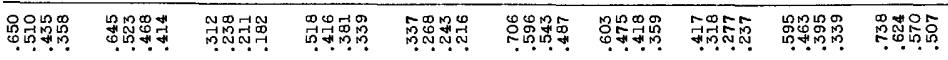

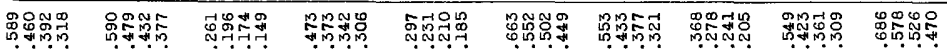

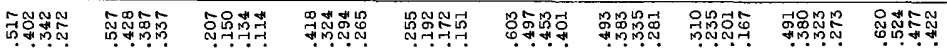

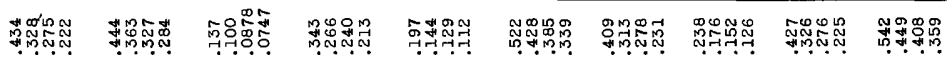

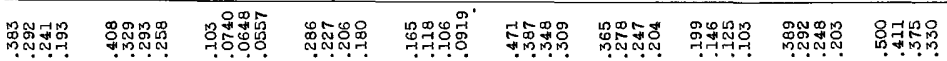

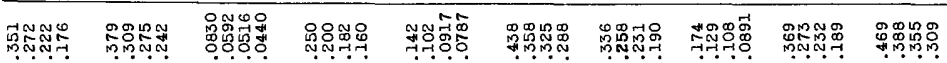

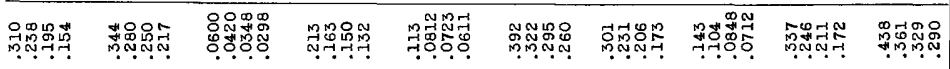

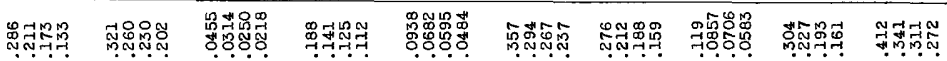

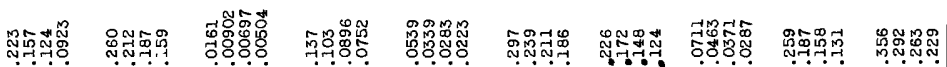

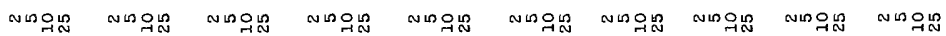

\begin{tabular}{|c|c|c|c|c|c|c|c|c|c|}
\hline జ్ & 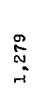 & 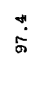 & 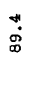 & $\stackrel{\mathcal{N}}{\mathrm{O}}$ & $\overrightarrow{7}$ & $\underset{-1}{-1}$ & $\stackrel{\mathbb{2}}{\sim}$ & 㤩 & $\stackrel{m}{7}$ \\
\hline 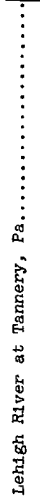 & 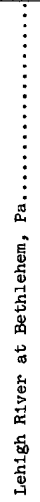 & 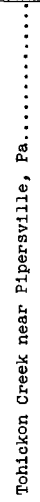 & 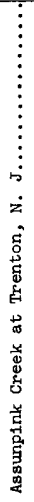 & 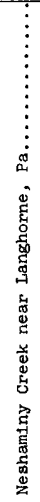 & 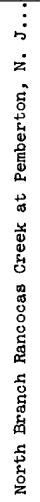 & 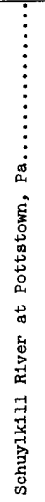 & 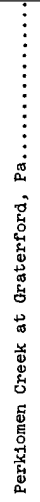 & 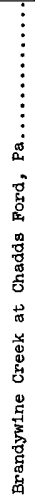 & 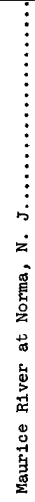 \\
\hline F & $\stackrel{\infty}{\infty}$ & "̈ & 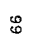 & $\stackrel{\infty}{\infty}$ & \& & $\stackrel{\mathfrak{R}}{\sim}$ & 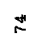 & $\mathscr{\infty}$ & \# \\
\hline
\end{tabular}




$$
\text { . }
$$



